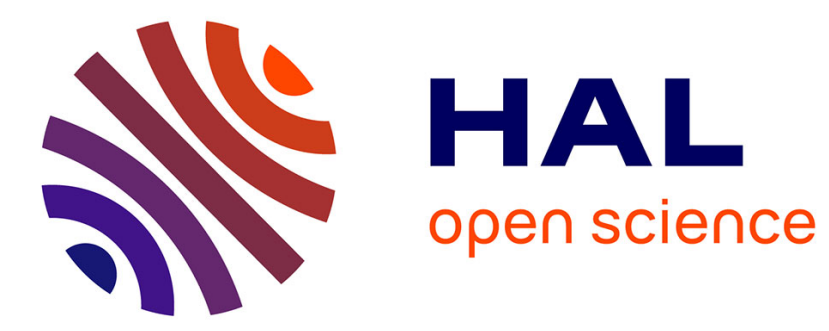

\title{
Mechanisms of soil carbon storage in experimental grasslands
}

\author{
S. Steinbeiss, V. M. Temperton, G. Gleixner
}

\section{To cite this version:}

S. Steinbeiss, V. M. Temperton, G. Gleixner. Mechanisms of soil carbon storage in experimental grasslands. Biogeosciences Discussions, 2007, 4 (5), pp.3829-3862. hal-00297929

\section{HAL Id: hal-00297929 \\ https://hal.science/hal-00297929}

Submitted on 19 Oct 2007

HAL is a multi-disciplinary open access archive for the deposit and dissemination of scientific research documents, whether they are published or not. The documents may come from teaching and research institutions in France or abroad, or from public or private research centers.
L'archive ouverte pluridisciplinaire HAL, est destinée au dépôt et à la diffusion de documents scientifiques de niveau recherche, publiés ou non, émanant des établissements d'enseignement et de recherche français ou étrangers, des laboratoires publics ou privés. 
Biogeosciences Discuss., 4, 3829-3862, 2007

www.biogeosciences-discuss.net/4/3829/2007/

(c) Author(s) 2007. This work is licensed

Mechanisms of soil carbon storage

S. Steinbeiss et al.

\section{Mechanisms of soil carbon storage in experimental grasslands}

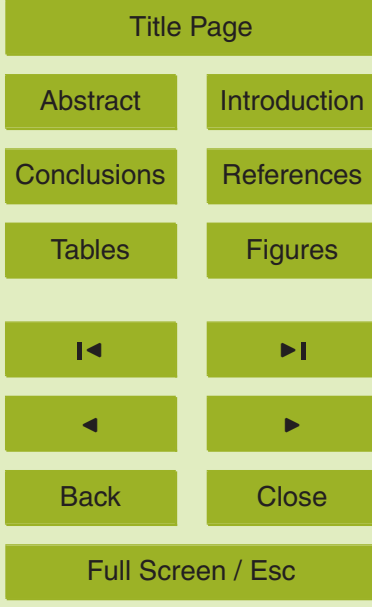

Printer-friendly Version

Interactive Discussion 


\section{Abstract}

We investigated the fate of root and litter derived carbon into soil organic matter and dissolved organic matter in soil profiles, in order to explain unexpected positive effects of plant diversity on carbon storage. A time series of soil and soil solution samples was 5 investigated at the field site of The Jena Experiment. In addition to the main biodiversity experiment with C3 plants, a C4 species (Amaranthus retroflexus L.) naturally labeled with ${ }^{13} \mathrm{C}$ was grown on an extra plot. Changes in organic carbon concentration in soil and soil solution were combined with stable isotope measurements to follow the fate of plant carbon into the soil and soil solution. A split plot design with plant litter removal versus double litter input simulated differences in biomass input. After 2 years, the no litter and double litter treatment, respectively, showed an increase of $381 \mathrm{~g} \mathrm{C} \mathrm{m}^{-2}$ and $263 \mathrm{~g} \mathrm{C} \mathrm{m}^{-2}$ to $20 \mathrm{~cm}$ depth, while $71 \mathrm{~g} \mathrm{C} \mathrm{m}^{-2}$ and $393 \mathrm{~g} \mathrm{C} \mathrm{m}^{-2}$ were lost between 20 and $30 \mathrm{~cm}$ depth. The isotopic label in the top $5 \mathrm{~cm}$ indicated that 11 and $15 \%$ of soil organic carbon were derived from plant material on the no litter and the double litter treatment, respectively. Without litter, this equals the total amount of carbon newly stored in soil, whereas with double litter this corresponds to twice the amount of stored carbon. Our results indicate that litter input resulted in lower carbon storage and larger carbon losses and consequently accelerated turnover of soil organic carbon. Isotopic evidence showed that inherited soil organic carbon was replaced by fresh plant carbon near the soil surface. Our results suggest that primarily carbon released from soil organic matter, not newly introduced plant organic matter, was transported in the soil solution and contributed to the observed carbon storage in deeper horizons.

\section{Introduction}

Increasing carbon storage in soils is one option helping to mitigate increasing atmospheric $\mathrm{CO}_{2}$ concentrations and global climate change (Lal, 2004b; Prentice, 2001).
BGD

4, 3829-3862, 2007

Mechanisms of soil carbon storage

S. Steinbeiss et al.

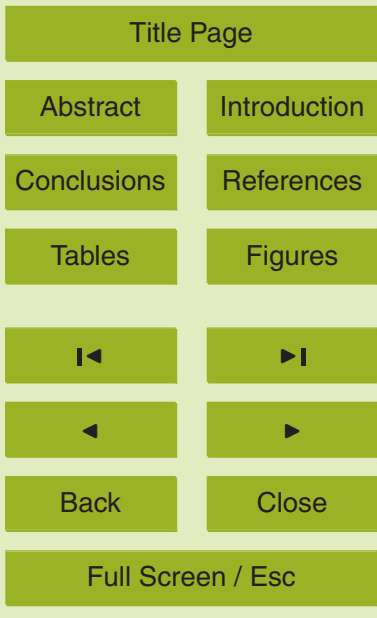

Printer-friendly Version

Interactive Discussion In terrestrial ecosystems plants are able to reduce atmospheric $\mathrm{CO}_{2}$ and bind it in 
biomass. The input of this plant material into the soil as roots or litter, stores carbon only during the short-term, however (Jenkinson, 1990; Parton et al., 1988). Roots are considered to be a more stable form of carbon supply to the soil than litter (Denef and Six, 2006). The latter causes priming of microbial decomposition and thus also 5 faster degradation of present soil organic carbon (SOC). Root material has a longer residence time in soil. It is chemically more recalcitrant, physico-chemically protected and gradually transformed to soil organic carbon (Rasse et al., 2005). The transformation of plant biomass to SOC by the activity of soil microbial communities is a potential source for long-term carbon storage (Rees et al., 2005).

10 Numerous investigations have shown that organic carbon stocks in soils are determined by the land use. Changing arable fields to managed grasslands, as on our field site, increases carbon concentrations in soil within a few years (Balesdent et al., 2000; Lal, 2004a; Romkens et al., 1999). At the same time the carbon distribution in the soil profile changes. In contrast to the homogeneous input of plant remains to 15 the plough horizon on arable fields, the input of plant material to soil in grasslands is controlled by the aboveground litter layer and the root distribution. As 70 to $75 \%$ of the root biomass in grasslands is located in the top $15 \mathrm{~cm}$ of the soil (Gill et al., 1999; Gleixner et al., 2005) organic carbon concentrations increase in the main rooting zone but decrease beneath this input source. Recent experimental evidence demonstrates that the type and diversity of plant species in grasslands plays an important role for carbon transfer into the soil and is able to modify carbon storage under a given land use scheme (Steinbeiss et al., $2007^{1}$; Tilman et al., 2006). As higher plant biodiversity leads to larger plant biomass (Balvanera et al., 2006; Lambers et al., 2004; Roscher et al., 2005) and therefore a larger biomass input into the soil, it is generally assumed that differences in input amounts (not quality of the input material) are responsible for the observed variation in carbon storage in soils (Catovsky et al., 2002; Skinner et al.,

\footnotetext{
${ }^{1}$ Steinbeiss, S., Bessler, H., Engels, C., Temperton, V. M., Buchmann, N., Roscher, C., Kreutziger, Y., Baade, J., and Gleixner, G.: Plant biodiversity positively affects carbon storage in experimental grasslands, Global Change Biology, submitted, 2007.
}

BGD

4, 3829-3862, 2007

Mechanisms of soil carbon storage

S. Steinbeiss et al.

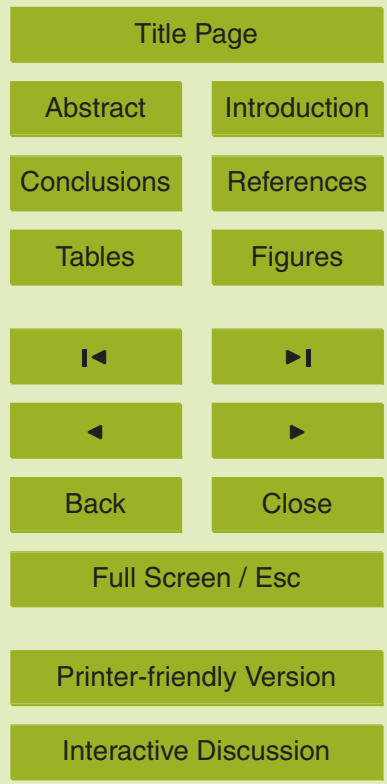

EGU 
2006). Soil microorganisms, however, might be especially activated by the input of fresh and easily decomposable plant material if a higher plant diversity increases the variability of compounds available as a nutrient source (Hooper et al., 2000; Stephan et al., 2000; Wardle et al., 1999). Different groups of soil microorganisms, such as 5 bacteria or fungi, use different carbon sources and therefore complement each other in resource utilization (Fontaine et al., 2003; Kramer and Gleixner, 2006). This so called priming effect, (defined as "strong short-term changes in turnover of soil organic matter caused by comparatively moderate treatments of the soil", Kuzyakov et al., 2000) not only transforms plant biomass to soil organic carbon but results in the decompo10 sition and mobilization of already present SOC (Fontaine et al., 2004; Fontaine and Barot, 2005). This mobilized carbon can be transported in soil solution and is exported from the microbial active zone near the roots. Water moving downwards then carries dissolved organic carbon (DOC) to deeper soil horizons, where it is preserved from complete mineralization. Gradually the transported compounds are readsorbed to soil 15 particles and contribute to carbon storage deeper in the soil profile (Kalbitz et al., 2005; Lajtha et al., 2005). So far it is unclear to what extent dissolved organic carbon in soil solution originates from plant decomposition products or mobilized soil organic carbon, and to what extent organic carbon is relocated by transport processes.

In our current study, stable carbon isotopes and their natural variability in plants with different photosynthetic pathways were used as tool to follow plant-derived carbon into the soil and soil solution carbon pools (Balesdent and Mariotti, 1996; Gleixner et al., 2002). As most plants in our geographical region possess a C3 photosynthetic pathway, the isotopic signature in soil organic carbon reflects typical $\delta^{13} \mathrm{C}$ values of $\mathrm{C} 3$ material in the range of about -25 to $-27 \%$. Growing plants with C4 photosynthesis, 25 that show $\delta{ }^{13} \mathrm{C}$ values between -12 and $-15 \%$ o, enabled us to quantify the proportion of fresh carbon incorporated into the soil and soil solution.

We hypothesized that the land use change from agricultural land to grassland would induce a change in carbon distribution in the soil resulting in increasing carbon content in the rooting zone and carbon losses below this source. Previous investigations of the

BGD

4, 3829-3862, 2007

Mechanisms of soil carbon storage

S. Steinbeiss et al.

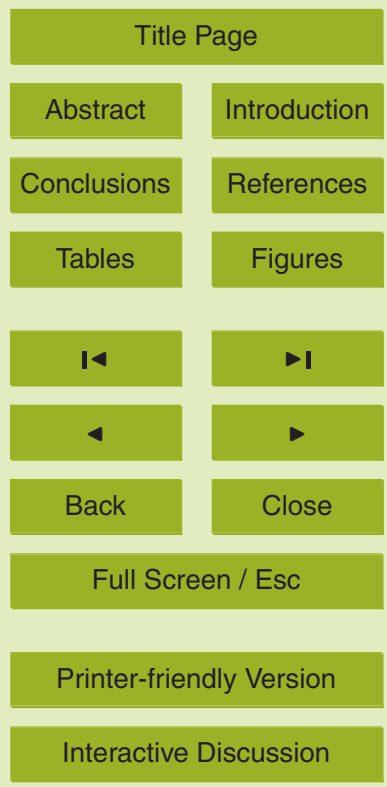

EGU 
influence of plant biodiversity on carbon storage showed that both, root biomass input and plant species richness explained soil carbon increase (Steinbeiss et al., $2007^{1}$ ). Therefore, the current study focused on the role of aboveground litter input on the development of the soil carbon pool, while root biomass input was held constant between

5 treatments by sowing the same plant species. We hypothesized that (1) the more litter is provided the more carbon is transferred to the soil and that (2) the soil solution is transporting plant-derived carbon from the soil surface as well as mobilized soil organic carbon into deeper soil horizons for storage.

\section{Materials and methods}

\section{$10 \quad 2.1 \quad$ Field site and plot design}

All samples were taken at the field site of The Jena Experiment, a managed grassland biodiversity experiment established in spring 2002 on the outskirts of Jena, Germany $\left(50^{\circ} 55^{\prime} \mathrm{N}, 11^{\circ} 35^{\prime} \mathrm{E}\right.$, altitude $\left.130 \mathrm{~m}\right)$. The field site was used as an arable field for the last 40 years and ploughed to a depth of about $30 \mathrm{~cm}$. The organic carbon concentration in 0 to $30 \mathrm{~cm}$ depth at the start of the experiment in spring 2002 was in the range from 10 to $29 \mathrm{~g} \mathrm{C} \mathrm{kg}^{-1}$, corresponding to a carbon stock of $7.3 \mathrm{~kg} \mathrm{C} \mathrm{m}^{-2}$ averaged for the whole field site. The carbonate content showed a strong spatial gradient and ranged between 4 and $42 \mathrm{~g} \mathrm{C} \mathrm{kg}^{-1}$.

The main biodiversity experiment consists of 86 plots $(20 \mathrm{~m} \times 20 \mathrm{~m})$ that contain mixtures of grassland species from a species pool of 60 species grouped into 4 functional groups. Detailed information about the field site, the species pool and the main experimental design can be found elsewhere (Roscher et al., 2004). At the same time as the main experiment an additional plot $(10 \mathrm{~m} \times 20 \mathrm{~m})$ was established with a $\mathrm{C} 4$ plant species (Amaranthus retroflexus L.) to achieve a natural isotopic label of carbon that enters the soil and the soil solution. Subsequently, this plot is referred to as C4 plot, while all other plots are $\mathrm{C} 3$ plots. The total initial carbon content in 0 to $30 \mathrm{~cm}$ depth

BGD

4, 3829-3862, 2007

Mechanisms of soil carbon storage

S. Steinbeiss et al.

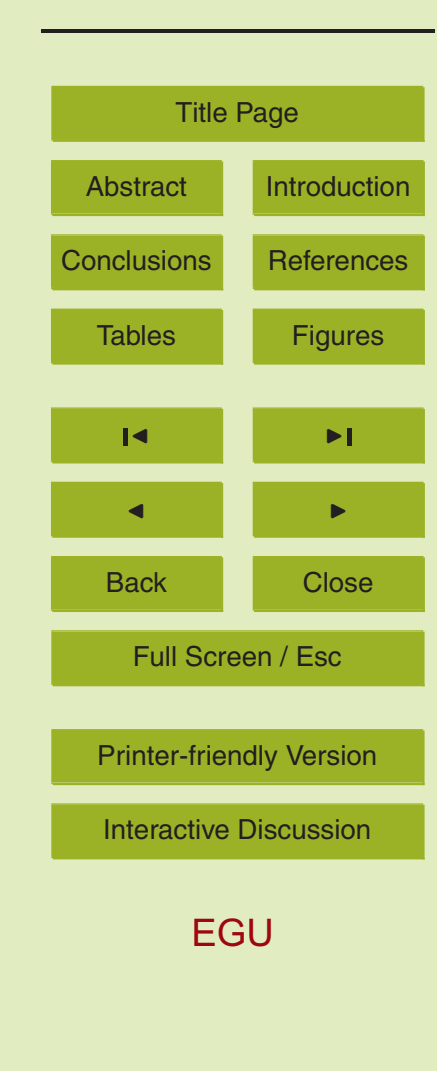


on this plot was $7.4 \mathrm{~kg} \mathrm{C} \mathrm{m}^{-2}$. The spatial variability within this plot (determined from five independent soil cores) depended on depth and ranged between 7.1 and $25.5 \%$, in which the higher variability was observed in depths below $20 \mathrm{~cm}$. On the C4 plot a split plot design was used to achieve differences in litter input. Thus, in fall 2002 and 52003 the mown above ground biomass (1000-1500 $\mathrm{g} \mathrm{m}^{-2} \mathrm{yr}^{-1}$ corresponding to 430$650 \mathrm{~g} \mathrm{C} \mathrm{m}^{-2} \mathrm{yr}^{-1}$ ) was removed from one half of the plot and added to the other half of the plot resulting in a no litter versus double litter treatment. On C3 plots the harvested above ground biomass was always removed from the plots.

The population of $\mathrm{C} 4$ plants was very dense, which kept weeds small and rare. Con-

\subsection{Soil sampling and analysis}

Stratified soil sampling was performed on all plots before sowing in April 2002 and was repeated in April 2004 to a depth of $30 \mathrm{~cm}$. In 2002, five independent samples per plot were taken using a split tube sampler with an inner diameter of $5 \mathrm{~cm}$ (Eijkelkamp

15 Agrisearch Equipment, Giesbeek, Netherlands). Soil samples were dried at $40^{\circ} \mathrm{C}$ and subsequently segmented to a depth resolution of $5 \mathrm{~cm}$ resulting in 6 samples per core. All samples were analyzed independently to calculate the spatial variability within the plots. In 2004, only 3 samples per plot were taken, whereas paired sampling was chosen to avoid additional spatial uncertainty (Lal et al., 2000). On the C4 plot 3 samples per treatment were taken. Soil samples were already segmented into their respective depths at the field and mixed to a plot or treatment representative sample per depth. Subsequently, samples were dried at $40^{\circ} \mathrm{C}$. All soil samples were passed through a sieve with a mesh size of $2 \mathrm{~mm}$. In 2002, rarely present visible plant remains were removed using tweezers. Due to much higher proportions of roots in the soil, the samples in 2004 were further sieved to $1 \mathrm{~mm}$ according to common root removal methods leaving finest roots in the soil light fraction (Allard et al., 2005; Ostonen et al., 2005; Stevens and Jones, 2006). No additional mineral particles were removed by this
BGD

4, 3829-3862, 2007

Mechanisms of soil carbon storage

S. Steinbeiss et al.

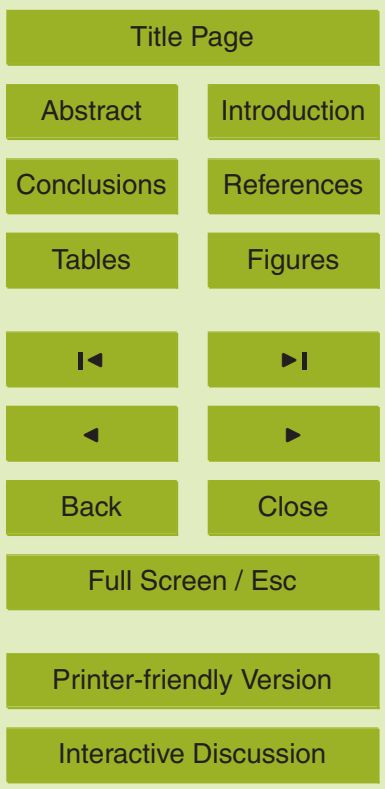

EGU 
procedure. Soil bulk density was determined from the soil sampling campaign in 2004. All soil samples taken with the split tube sampler were weighed and the inner diameter of the soil corer was used for volume calculation.

Total carbon concentration was analyzed on ball-milled subsamples (time 4 min, fre5 quency $30 \mathrm{~s}^{-1}$ ) by an elemental analyzer at $1150^{\circ} \mathrm{C}$ (Elementaranalysator vario Max $\mathrm{CN}$, Elementar Analysensysteme $\mathrm{GmbH}$, Hanau, Germany). To determine the organic carbon concentration either the carbonate or the organic compounds had to be removed (Bisutti et al., 2004). We measured inorganic carbon concentration by elemental analysis after removal of organic carbon for $16 \mathrm{~h}$ at $450^{\circ} \mathrm{C}$ in a muffle furnace (Steinbeiss et al., $2007^{1}$ ). The organic carbon concentration was then calculated from the difference between both measurements. The reliability of this method was proven by measuring certified reference soil material (HEKAtech GmbH, Wegberg, Germany) on a regular basis. The repeated measurements of the soil standard resulted in a relative standard deviation for organic carbon concentration measurements of $1.2 \%$.

15 All soil samples were analyzed for $\delta^{13} \mathrm{C}$ values of the organic carbon. For this, $3 \mathrm{mg}$ ground soil was weighed in small tin capsules and treated with $120 \mu \mathrm{l}$ of sulfurous acid (5-6\% $\mathrm{SO}_{2}$, Merck, Darmstadt, Germany) to remove inorganic carbon. Subsequently, the samples were dried at $60^{\circ} \mathrm{C}$ and measured by a coupling of an elemental analyzer (EA 1110) with an isotope ratio mass spectrometer (DeltaPlusXL, Thermo Finnigan, Bremen, Germany) (EA-IRMS). All values represent repeated measurements with a standard deviation of less than $0.3 \%$ and were calibrated versus V-PDB using $\mathrm{CO}_{2}$ as reference gas (Werner and Brand, 2001).

\subsection{Soil water sampling and analysis}

In April 2002 glass suction plates with a diameter of $12 \mathrm{~cm}, 1 \mathrm{~cm}$ thickness and a pore 25 size of 1 to $1.6 \mu \mathrm{m}$ (UMS GmbH, Munich, Germany) were installed in depths of 10 , 20 and $30 \mathrm{~cm}$ to collect soil solution. Suction plates on the C4 double litter treatment were added in May 2003 in the same depths. The sampling bottles were continuously evacuated to a negative pressure between 50 and 350 mbar depending on the actual

BGD

4, 3829-3862, 2007

Mechanisms of soil carbon storage

S. Steinbeiss et al.

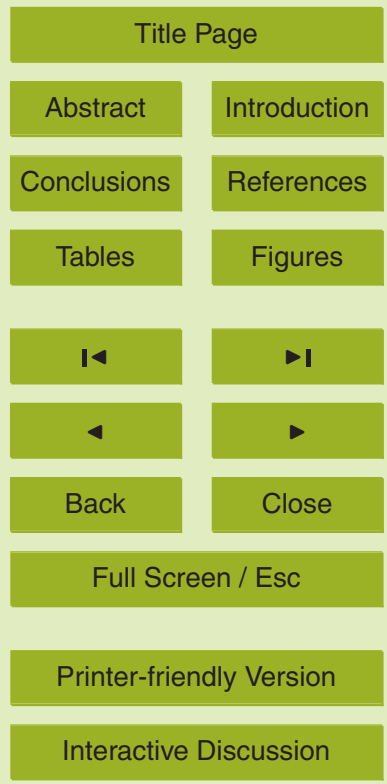

EGU 
soil water tension. Thus, only free soil water was collected. Cumulative soil solution was sampled biweekly and analyzed for dissolved organic carbon concentration by a highTOC elemental analyzer (Elementar Analysensysteme $\mathrm{GmbH}$, Hanau, Germany). Samples were analyzed as soon as possible and stored at $4^{\circ} \mathrm{C}$ if necessary. Between 5 mid of June and mid of September 2003 no free soil solution was available for collection in $10 \mathrm{~cm}$ depth. Remoistening of the soil profile took until end of November in $30 \mathrm{~cm}$ depth.

The water remaining after concentration measurements was freeze dried and the corresponding $\delta^{13} \mathrm{C}$ values of DOC were measured by EA-IRMS after carbonate re10 moval, which was performed as with soil samples. $120 \mu \mathrm{l}$ of sulfurous acid were added to $2 \mathrm{mg}$ freeze dried material and dried at $60^{\circ} \mathrm{C}$ before measurement. During summer sample amounts often were too small for isotope analysis. Therefore, samples were stored at $-20^{\circ} \mathrm{C}$, pooled with the next sampling and analyzed as mixed sample.

Cumulative annual export amounts of DOC for both treatments on the C4 plot were 15 calculated using the collected volumes. The time frame was adapted to the seasonal cycle and vegetation period of the C4 species and thus started in May 2003 and ended in April 2004. The collected volumes will differ from real water fluxes; however, due to the continuous vacuum system the calculated values represent the maximum soil water efflux. The calculation primarily aimed to compare both treatments instead of calculating a carbon balance. Suction plates in the respective depths of both treatments were coupled to the same vacuum device. We assumed that error sizes were the same for all depths and both treatments. Thus, a larger volume collected at the same time on the double litter treatment compared to the no litter treatment was interpreted as higher soil moisture and larger water flux.

For correlations of the time series of DOC concentration with soil moisture and soil temperature continuous measurements from the meteorological station near the C4 plot were used. Soil temperature and soil moisture were averaged for the respective depths for the time frame between two soil solution sampling dates.

\section{BGD}

4, 3829-3862, 2007

Mechanisms of soil carbon storage

S. Steinbeiss et al.

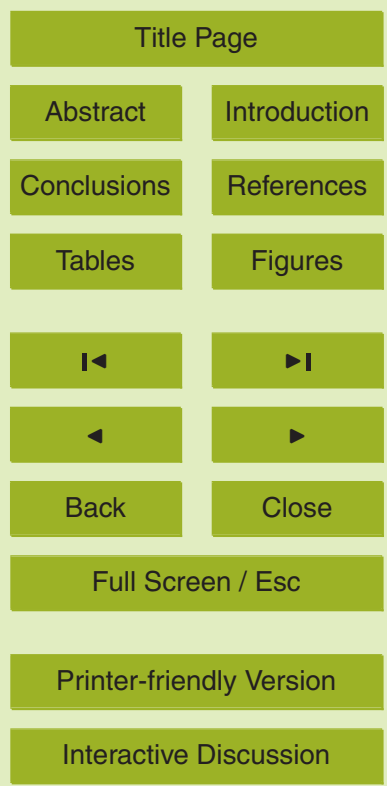

EGU 
Above ground plant biomass was harvested twice a year on the C3 plots, in May and August, and the biomass was removed from the plots. Amaranthus retroflexus L. was an annual species that started growing in May each year. Therefore, the C4 plot was 5 only mown once a year in August.

Above ground plant material from biomass harvests in 2003 was used to determine community carbon isotope contents of the C3 plots. The plants were cut $3 \mathrm{~cm}$ above the ground on four randomly selected quadrat sample areas of $20 \mathrm{~cm} \times 50 \mathrm{~cm}$ and a plot representative mixture of all species was used for isotope analyses. Carbon isotope values of the $\mathrm{C} 4$ species were determined from harvested above ground plant material in August 2003. Below ground carbon isotope ratios of the C4 species in both treatments were determined from root material sieved out of the soil samples taken in spring 2004. All plant samples were dried at $70^{\circ} \mathrm{C}$ for $48 \mathrm{~h}$ and ground with a ball mill prior to chemical analysis. Between 1 and $2 \mathrm{mg}$ sample was weighed in tin capsules and measured by EA-IRMS as for the soil samples.

Root standing biomass (expressed as $\mathrm{g} \mathrm{C} \mathrm{m}^{-2}$ ) and root distribution on the $\mathrm{C} 4$ treatments was estimated from the root material that was sieved out from the soil samples taken in 2004.

\subsection{Calculation of fraction of plant-derived carbon in soil and soil solution}

20 Based on the changes of $\delta^{13} \mathrm{C}$ values of SOC on the $\mathrm{C} 4$ treatments after the vegetation change from C3 to C4 plants in spring 2002 and the isotopic difference of the C3 and $\mathrm{C} 4$ plants, it is possible to calculate the fraction $\mathrm{F}$ of fresh carbon in the soil carbon pool (Balesdent and Mariotti, 1996; Gleixner et al., 1999).

$\mathrm{F}=\frac{\left(\delta^{13} \mathrm{C}_{\mathrm{C} 4 \text {-soil }}-\delta^{13} \mathrm{C}_{\mathrm{C} 3 \text {-soil }}\right)}{\left(\delta^{13} \mathrm{C}_{\mathrm{C} 4 \text {-plant }}-\delta^{13} \mathrm{C}_{\mathrm{C} 3 \text {-plant }}\right)}$

\section{BGD}

4, 3829-3862, 2007

Mechanisms of soil carbon storage

S. Steinbeiss et al.

Title Page

Abstract

Introduction

Conclusions

References

Tables

Figures

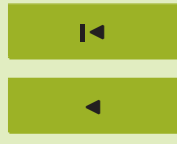

$\rightarrow 1$

Back

Close

Full Screen / Esc

Printer-friendly Version

Interactive Discussion 
For C3 soil the average of $\delta^{13} \mathrm{C}$ values of the respective depth from all C3 plots measured in 2004 was used, thus considering changes independently of C3-C4 vegetation change. For the $\delta^{13} \mathrm{C}$ value representing the $\mathrm{C} 3$ plants, a community value was calculated by averaging the above ground plot data of all species in a plot in 2003 paying 5 attention to the relative abundance of the different species in the mixtures. All mean values of the plots were then averaged to get the overall C3 signal and the standard deviation given corresponds to this overall value. Due to the litter removal versus double litter input on the C4 treatments, two calculations were performed. We compared the results using the $\delta^{13} \mathrm{C}$ value of above ground biomass of the $\mathrm{C} 4$ plants with results using the root biomass isotope values. Results given refer to the calculation with treatment specific root biomass isotope values for $\mathrm{C} 4$ plants.

Calculation of the proportion of $\mathrm{C} 4$ carbon in DOC was based on the difference between the measured carbon isotope value of DOC at the sampling date and a reference value representing the background value or largest possible difference. We took the 15 carbon isotope values of SOC measured in 2004 on the respective treatments and depths as reference values. The isotopic composition of SOC shifted within the investigation period and the measurements of 2004 represent the end member of the time series. The SOC values in 2004 fairly agreed with the background ${ }^{13} \mathrm{C}$ values measured for DOC in the respective depths. This difference was related to the difference in 20 the $\delta^{13} \mathrm{C}$ values of the possible DOC sources $\mathrm{C} 4$ plant carbon and soil organic carbon without C4 signature (2002 values). The isotope values of the SOC were adapted to the depth resolution of the suction plates $(10 \mathrm{~cm})$ paying attention to the carbon concentration gradient in soil.

$\mathrm{F}=\frac{\left(\delta^{13} \mathrm{C}_{\mathrm{DOC}}-\delta^{13} \mathrm{C}_{\mathrm{SOC2004}}\right)}{\left(\delta^{13} \mathrm{C}_{\mathrm{C} 4-\text { plant }}-\delta^{13} \mathrm{C}_{\mathrm{SOC} 2002}\right)}$

\section{BGD}

4, 3829-3862, 2007

Mechanisms of soil carbon storage

S. Steinbeiss et al.

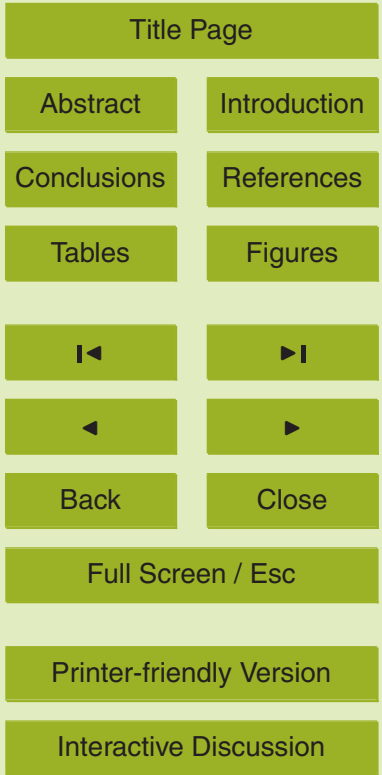




\section{Results}

\subsection{Soil organic carbon (SOC) and isotope ratios}

In the main experiment, repeated soil sampling at the start of the experiment and after 2 years revealed an average increase in soil organic carbon in the top $5 \mathrm{~cm}$ of $92 \mathrm{~g} \mathrm{C} \mathrm{m}^{-2}$ 5 corresponding to a $7.5 \%$ increase compared to the initial value of 2002 (Fig. 1). At the same time organic carbon stocks strongly decreased below $20 \mathrm{~cm}$ depth. Between 20 and $30 \mathrm{~cm}$ depth on average $382 \mathrm{~g} \mathrm{C} \mathrm{m}^{-2}$ were lost, which corresponded to a decline of $15.3 \%$. In the C4 treatments soil organic carbon increased to a depth of $20 \mathrm{~cm}$ but also decreased below this depth (Fig. 1). In the no litter treatment the observed increase in soil organic carbon in the depth segments to $20 \mathrm{~cm}$ were between 88 and $106 \mathrm{~g} \mathrm{C} \mathrm{m}^{-2}$ (in total $381 \mathrm{~g} \mathrm{C} \mathrm{m}^{-2}$ ) corresponding to a relative increase of 6.6 to $10.0 \%$ compared to the initial values of 2002 . Despite the additional carbon source, double litter input resulted in a lower increase in soil organic carbon. In the depth segments to $20 \mathrm{~cm} 47$ to $78 \mathrm{~g} \mathrm{C} \mathrm{m}^{-2}$ (in total $263 \mathrm{~g} \mathrm{C} \mathrm{m}^{-2}$ ) were stored corresponding to a relative increase of 3.8 to $7.7 \%$. Differences between the treatments were significant in the depth segments from 0 to $5 \mathrm{~cm}$ and 10 to $15 \mathrm{~cm}(p<0.05)$. The decrease in soil organic carbon below $20 \mathrm{~cm}$ depth differed strongly between the treatments (Fig. 1). In the no litter treatment $71 \mathrm{~g} \mathrm{C} \mathrm{m}^{-2}$ were lost between 20 and $30 \mathrm{~cm}$ depth, while in the double litter treatment the organic carbon content decreased as much as $393 \mathrm{~g} \mathrm{C} \mathrm{m}^{-2}$ in the 20 same depth. Neither the absolute changes in soil organic carbon nor the difference between the treatments on the $\mathrm{C} 4$ plot followed the estimated root distribution pattern in the treatments (Fig. 2).

To describe the carbon sources responsible for the observed increase in carbon content in the upper $20 \mathrm{~cm}$ of the soil, we used analyses of changes in the soil organic 25 carbon isotope signal of the $\mathrm{C} 4$ treatments compared to the $\mathrm{C} 3$ plots. This enabled us

to distinguish between the input of fresh plant-derived carbon holding a C4 signal and the relocation of already present SOC holding a $\mathrm{C} 3$ signal of the former vegetation. In 2002, the $\delta^{13} \mathrm{C}$ value of SOC on the C4 plot between 0 and $30 \mathrm{~cm}$ depth was $-26.6 \%$ 。

BGD

4, 3829-3862, 2007

Mechanisms of soil carbon storage

S. Steinbeiss et al.

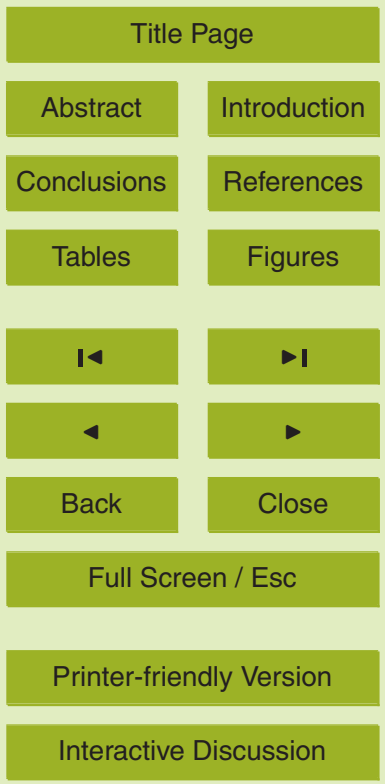

EGU 
throughout the depth profile $(\mathrm{sd}=0.1)$. The plot variability in terms of $\delta^{13} \mathrm{C}$ values of SOC determined from the independent soil cores taken in 2002 was between 0.02 and $0.34 \%$ o depending on depth. On average a standard deviation of $0.24 \%$ was observed.

For calculation of proportions of $\mathrm{C} 4$ carbon in soil the isotope values of treatment 5 specific root biomass of the $\mathrm{C} 4$ species was used. On the no litter treatment the root material had $\delta^{13} \mathrm{C}$ values of $-14.1 \%$, while on the double litter treatment $-15.1 \%$ o were measured. Above ground C4 biomass held isotope ratios of $-13.2 \%$ o in 2003. The average isotope signal of above ground C3 plot communities in 2003 at the field site was $-28.9 \%$ o ( $\mathrm{sd}=0.7)$.

10 Between 2002 and 2004 the average organic carbon isotope signal of all C3 plot soil increased continuously with increasing depth, starting from no change in the top $5 \mathrm{~cm}$ to a difference of $0.4 \%$ in 25 to $30 \mathrm{~cm}$ depth (Fig. 3). This shift in the $\delta^{13} \mathrm{C}$ values was significantly correlated to the average decrease in the organic carbon concentration on all C3 plots with soil depth $(\mathrm{R}=0.98$ and $\mathrm{p}<0.001)$. The $\delta^{13} \mathrm{C}$ values of both treatments on the C4 plot clearly shifted to C4 plant specific isotope signals in the top $5 \mathrm{~cm}$ of the soil. Double litter input resulted in a $\delta^{13} \mathrm{C}$ value of $-24.9 \%$, which corresponded to a shift of $1.9 \%$ between 2002 and 2004 . The organic carbon isotope signal in the soil with no litter treatment shifted $1.4 \%$ o to a $\delta^{13} \mathrm{C}$ value of $-25.4 \%$ o in the top $5 \mathrm{~cm}$ (Fig. 3). With increasing depth the $\mathrm{C} 4$ signal weakened and could not be observed any longer 20 in $20 \mathrm{~cm}$ depth, where $\delta^{13} \mathrm{C}$ values of $-26.5 \%$ o were measured on both treatments in 2004. Below $20 \mathrm{~cm}$ depth, the input of $\mathrm{C} 4$ plant carbon from roots added with the soil organic carbon loss, which both led to increasing $\delta^{13} \mathrm{C}$ values. The resulting shift in the $\delta^{13} \mathrm{C}$ values in 25 to $30 \mathrm{~cm}$ depth was 0.4 and $0.6 \%$ on the no litter and double litter treatment, respectively.

25 The changes in $\delta^{13} \mathrm{C}$ values in the soil on the $\mathrm{C} 4$ plot after the vegetation change from C3 to C4 plants in spring 2002 were used to calculate the fraction of fresh plantderived carbon in the soil carbon pool (see method's section for details). We performed calculations for depths up to $20 \mathrm{~cm}$, where carbon storage was observed after 2 years. The relative change in SOC was then compared to the detected C4 label in 2004 to dif-

BGD

4, 3829-3862, 2007

Mechanisms of soil carbon storage

S. Steinbeiss et al.

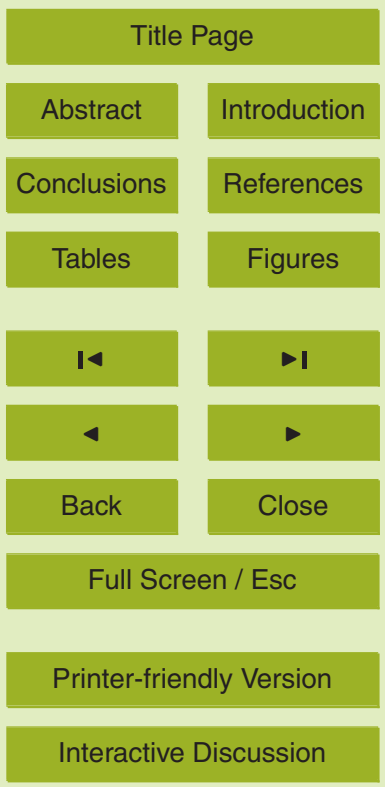

EGU 
ferentiate between plant sources and the proposed relocation of already present SOC holding a C3 signal (Fig. 4). The comparison differentiates between 3 cases, represented by the $1: 1$ line in Fig. 4. Data points above the 1:1 line, i.e. double litter treatment at depth $0-5 \mathrm{~cm}$, have a higher proportion of $\mathrm{C} 4$ carbon in the soil organic carbon 5 pool compared to the corresponding storage of soil organic carbon after 2 years. This indicates a loss of carbon with C3 signature from the soil segment in question. For data points matching the $1: 1$ line, i.e. double litter treatment at depths $5-10$ and $10-15 \mathrm{~cm}$ and no litter treatment at depth $0-5 \mathrm{~cm}$, one can assume that any increase in soil organic carbon was attributed to the input of fresh C4 plant material. Decomposition that 10 took place did not favor "fresh" C4 or "old" C3 carbon. Data points below the 1:1 line, i.e. double litter treatment at depth $15-20 \mathrm{~cm}$ and no litter treatment at depths 5-10, $10-15$ and $15-20 \mathrm{~cm}$, indicate the relocation of already present soil organic carbon holding the $\mathrm{C} 3$ signature of the plants prior to the $\mathrm{C} 3-\mathrm{C} 4$ vegetation change. The comparison between treatments (no litter versus double litter) revealed clear differences in 15 the sources of carbon storage in the depth profile.

The increase in soil organic carbon in the no litter treatment in the top $5 \mathrm{~cm}$ of the soil profile was due to the input of new $\mathrm{C} 4$ plant material, i.e. decaying roots. The calculated C4 label matched the observed carbon increase (Fig. 4). Below $5 \mathrm{~cm}$ depth the increase in organic carbon exceeded the detected label of $\mathrm{C} 4$ plant material. Thus, organic carbon with $\mathrm{C} 3$ signature contributed to the observed carbon storage.

In the double litter treatment the calculated C4 label of the soil organic carbon pool exceeded the increase in organic carbon in the top $5 \mathrm{~cm}$ of the soil profile (Fig. 4). After 2 years the calculated fraction of fresh carbon from C4 plants was 15\% in the top $5 \mathrm{~cm}$ of the soil, while the carbon content only increased by $7.7 \%$ in the same depth segment. Between 5 and $15 \mathrm{~cm}$ depth the $\mathrm{C} 4$ label matched the observed carbon storage. As in the no litter treatment, in $15-20 \mathrm{~cm}$ depth most of the carbon storage was attributed to $\mathrm{C} 3$ labeled carbon. About $2 \% \mathrm{C} 4$ label stand against $6 \%$ increase in soil organic carbon content (Fig. 4).

BGD

4, 3829-3862, 2007

Mechanisms of soil carbon storage

S. Steinbeiss et al.

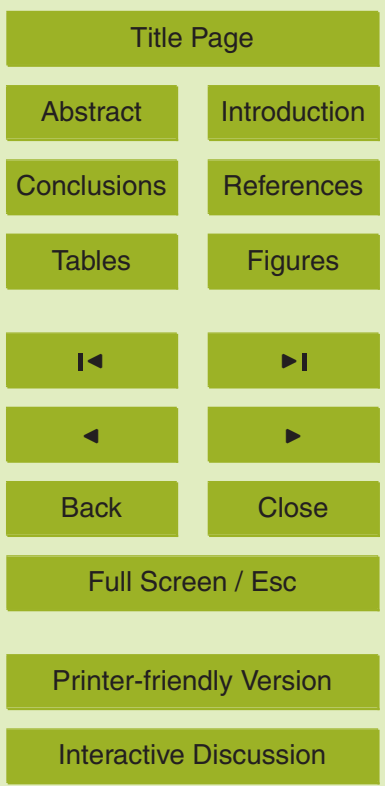

EGU 
DOC concentration in soil solution showed seasonal patterns with maximum concentration in summer and early fall and minimum concentration in late winter on all plots. We observed no general differences between both $\mathrm{C} 4$ treatments (Fig. $5 a$ and b). The 5 increase of DOC concentration in spring coincided with rising soil temperatures and drying out processes. The decrease of DOC concentration in fall was strongly correlated to soil remoistening (Table 1) and hence a dilution effect. The correlation between soil temperature and DOC concentration in fall decreased with increasing depth. Overall, between $77 \%$ (20 cm depth) and $90 \%(30 \mathrm{~cm})$ of the seasonal variability in DOC concentration was explained by soil moisture and soil temperature. In winter, the highest DOC concentration was measured in $30 \mathrm{~cm}$ depth (about $12 \mathrm{mgl}^{-1}$ ) due to lower water availability. Saturation of the soil water potential in the observation year in this depth was not reached before spring 2004 . In $10 \mathrm{~cm}$ depth winter DOC concentration was about $9 \mathrm{mgl}^{-1}$. The most pronounced difference between the no litter and double 15 litter treatment was the faster decrease in DOC concentration in fall in $10 \mathrm{~cm}$ depth on the double litter treatment. For comparison of the treatments cumulative organic carbon export amounts per year were calculated.

In $2003,95 \%$ of the annual DOC export with soil solution took place in fall and winter (Fig. 6). Calculation of the organic carbon export amount from $10 \mathrm{~cm}$ depth between 20 May 2003 and May 2004 resulted in $8.1 \mathrm{~g} \mathrm{C} \mathrm{m}^{-2}$ in both the no litter and the double litter treatment.

Deeper in the soil profile, differences between the litter treatments appeared. In the no litter treatment, DOC export amounts decreased linearly with increasing depth $\left(8.1 \mathrm{~g} \mathrm{C} \mathrm{m}^{-2}, 5.4 \mathrm{~g} \mathrm{C} \mathrm{m}^{-2}\right.$ and $3.3 \mathrm{~g} \mathrm{C} \mathrm{m}^{-2}$ from 10,20 and $30 \mathrm{~cm}$ depth, respectively) 25 (Fig. 6a). In the double litter treatment $30 \%$ less organic carbon was exported from $20 \mathrm{~cm}$ depth $\left(3.8 \mathrm{~g} \mathrm{C} \mathrm{m}^{-2}\right)$ than in the no litter treatment (Fig. $\left.6 \mathrm{~b}\right)$. In $30 \mathrm{~cm}$ depth DOC export amounts were larger in the double litter treatment $\left(4.3 \mathrm{~g} \mathrm{C} \mathrm{m}^{-2}\right)$ than in the no litter treatment, which coincided with the observed higher carbon losses in the soil pool

4, 3829-3862, 2007

Mechanisms of soil carbon storage

S. Steinbeiss et al.

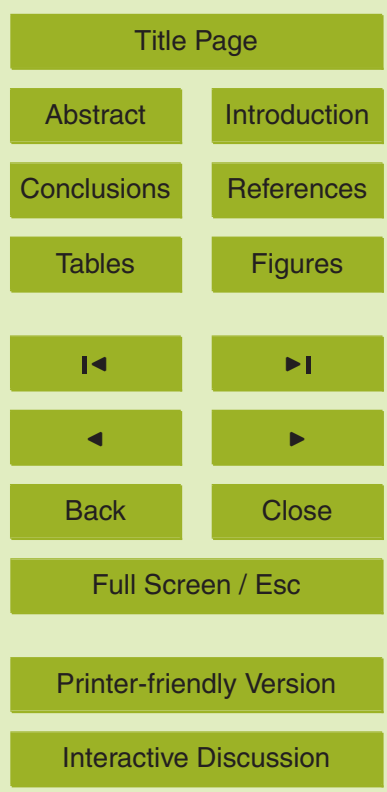

EGU 
in this depth.

Carbon isotope signals of DOC in the soil solution collected in 2003 on C3 plots showed a seasonal variability between $-27.9 \%$ and $-28.4 \%$ in 10 and $20 \mathrm{~cm}$ depth and $-27.2 \%$ and $-28.0 \%$ in $30 \mathrm{~cm}$ depth (Fig. $7 \mathrm{a}$ ). Thus, $\delta^{13} \mathrm{C}$ values slightly

5 increased with increasing depth and shifted from the C3 plant community signal $(-28.9 \%$ o) towards the isotope value of present SOC (-26.4\% in 20 to $30 \mathrm{~cm}$ depth). The shift from plant signature towards soil isotope values occurred also in the C4 treatments. There, decreasing $\delta^{13} \mathrm{C}$ values were measured with increasing depth throughout the seasons (Fig. 7b and c). The increase in DOC concentration in spring and first 10 data after summer dryness were not accompanied by $\delta{ }^{13} \mathrm{C}$ values of $\mathrm{C} 4$ plant material. Average isotope ratios during this time ranged from $-25.8 \%$ in the no litter treatment and $-24.7 \%$ in the double litter treatment in $10 \mathrm{~cm}$ depth to $-26.6 \%$ in 20 and $30 \mathrm{~cm}$ depth in both treatments. In 10 and $20 \mathrm{~cm}$ depth they matched the $\delta^{13} \mathrm{C}$ values of the soil organic carbon in the respective soil layer measured in 2004 , i.e. $-25.3 \%$ and $15-24.9 \%$ o in $10 \mathrm{~cm}$ in no litter and double litter treatment, respectively, and $-26.5 \%$ o in $20 \mathrm{~cm}$ in both treatments.

In November 2003 decomposition of plant remains led to an increase in the plant derived fraction of DOC primarily in $10 \mathrm{~cm}$ depth (Fig. $7 \mathrm{~b}$ and $\mathrm{c}$ ). The proportion of $\mathrm{C} 4$ material in DOC was larger with double litter input and the label was observed for about 3 months. In the no litter treatment we measured up to $-24.0 \%$, which corresponded to a proportion of $14 \%$ of plant derived material in the DOC. The label showed up as a sharp peak that already disappeared two weeks later. The calculated proportion of C4 carbon in soil solution in this depth and treatment was usually less than $5 \%$ the rest of the year. Isotope values of more than $-23.0 \%$ o (corresponding to more than $20 \% \mathrm{C} 4$ carbon in the soil solution) were observed in the double litter treatment between mid of November 2003 and end of January 2004. The maximum value reached $-21.7 \%$, which corresponded to a proportion of $29 \%$ of C4 plant derived carbon. After litter deposition generally higher proportions of $\mathrm{C} 4$ carbon in soil solution were observed than in the no litter treatment (between 10 and 17\%) within the investigation period.

BGD

4, 3829-3862, 2007

Mechanisms of soil carbon storage

S. Steinbeiss et al.

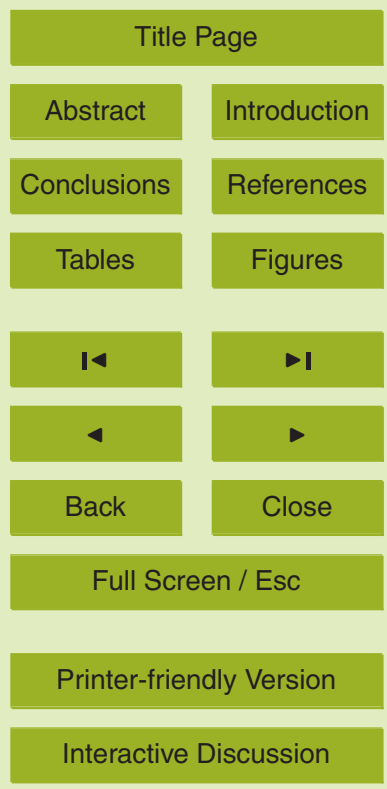

EGU 
DOC composition changed with increasing depth as SOC contained no C4 marked material in $20 \mathrm{~cm}$ depth, as shown in the soil section above, and in the double litter treatment the spatial distance to the litter layer increased. The maximum $\delta^{13} \mathrm{C}$ value in $20 \mathrm{~cm}$ depth (-25.2\%) was observed at the same time as in $10 \mathrm{~cm}$ depth in the no litter 5 treatment, and still corresponded to $9 \%$ of plant derived carbon. In the double litter treatment the decrease of the proportion of $\mathrm{C} 4$ carbon in soil solution with depth was more pronounced. The maximum $\delta^{13} \mathrm{C}$ value of $-24.4 \%$ corresponded to a proportion of only $14 \%$ C4 carbon. Additionally, a time lag of several weeks occurred between the start of the $\mathrm{C} 4$ signal in $20 \mathrm{~cm}$ depth compared to the $10 \mathrm{~cm}$ depth (Fig. $7 \mathrm{a}$ ). In $1030 \mathrm{~cm}$ depth no clear $\mathrm{C} 4$ signal could be detected in soil solution of both treatments. Seasonal differences in $\delta^{13} \mathrm{C}$ values in this depth were $1 \%$ at most. All plant derived carbon that entered the soil solution above this depth was completely mineralized or adsorbed to soil particles already.

\section{Discussion}

\subsection{Soil organic carbon}

Our current study confirmed the hypothesis of a changing organic carbon distribution in the soil profile being caused by the land use change from arable land to managed grassland. As a result of the land use change, soil organic carbon increased to a depth of $10 \mathrm{~cm}$ in the main experiment with C3 plants, and even to a depth of $20 \mathrm{~cm}$ in the additional experiment using $\mathrm{C} 4$ plants. Carbon losses were generally observed below $20 \mathrm{~cm}$ depth. Different litter treatments on the C4 plot did not cause main differences in root biomass production or root distribution as was shown in the similar depth profile of standing root biomass after 2 years.

Surprisingly, the extra litter layer did not result in a larger increase in soil organic increase in SOC to a depth of $20 \mathrm{~cm}$ tend to be smaller beneath the litter layer, but

BGD

4, 3829-3862, 2007

Mechanisms of soil carbon storage

S. Steinbeiss et al.

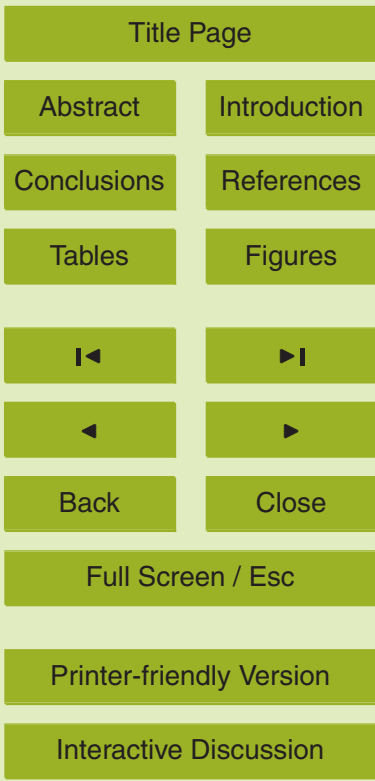

EGU 
also the carbon loss below $20 \mathrm{~cm}$ depth was significantly larger in this treatment. The litter input may have induced a priming of microbial decomposition in soil that resulted in faster turnover rates and a mobilization of already present soil organic carbon as was found in other investigations (Fontaine et al., 2004). As a result, the incorporated 5 proportion of plant derived carbon in the SOC pool with the double litter treatment was larger than the observed increase in SOC nearest to the litter layer, which means in the top $5 \mathrm{~cm}$ of the soil profile (Fig. 4). In this layer, isotopic measurements showed that the proportion of plant derived carbon in SOC was twice the observed SOC increase. On the other hand, between 15 and $20 \mathrm{~cm}$ depth organic carbon holding a C3 isotope 10 signal clearly dominated the organic carbon storage in the soil. We therefore conclude that the above mobilized soil organic carbon was not lost completely by mineralization processes but was transported in the soil solution and readsorbed to soil particles as it moved through the soil profile.

In the no litter treatment, the proportion of plant derived carbon in the top $5 \mathrm{~cm}$ of 15 the soil profile equaled the increase in SOC indicating no preferential decomposition of plant derived carbon or the existing soil organic carbon pool. Even though the soil organic carbon still increased between 5 and $20 \mathrm{~cm}$ depth in this treatment, this increase was not accompanied by an adequate increase in $\delta^{13} \mathrm{C}$ values of the SOC pool, as would be expected had the carbon source been recent $\mathrm{C} 4$ plant material. There are two possible explanations for this observation, which most probably both contribute to the observed results of our experiment.

1) The simplest explanation takes the spatial variability of about $10 \%$ in soil organic carbon stocks within a plot (determined in 2002) into account. This would leave the possibility that (also in the no litter treatment) mobilized SOC with a C3 signature was relocated by soil solution from the upper $5 \mathrm{~cm}$ of the soil profile to a depth of $10-20 \mathrm{~cm}$, where it contributed to the observed increase in SOC.

2) The second explanation suggests an additional carbon source with $\mathrm{C} 3$ signature that can be utilized by soil microorganisms. This theory is supported by an investigation, where up to $40 \%$ of the carbon used by microorganisms was not SOC or plant

BGD

4, 3829-3862, 2007

Mechanisms of soil carbon storage

S. Steinbeiss et al.

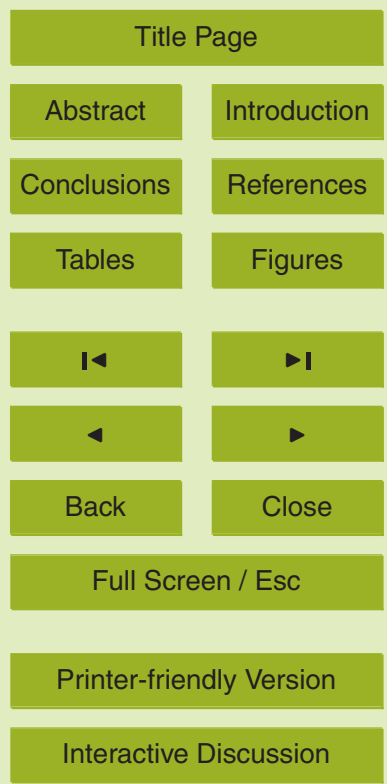

EGU 
derived carbon (Kramer and Gleixner, 2006). Probably, microorganisms are able to utilize $\mathrm{CO}_{2}$ that is set free by mineralization of $\mathrm{SOC}$ below $20 \mathrm{~cm}$ depth, which diffuses upwards and holds the $\mathrm{C} 3$ signature of its source. Our findings demonstrated that the major part of organic carbon below $20 \mathrm{~cm}$ depth was lost by mineralization. The DOC 5 export by soil solution between 20 and $30 \mathrm{~cm}$ depth explained less than $10 \%$ of the observed carbon losses from the SOC pool and the correlation between carbon loss and increasing $\delta^{13} \mathrm{C}$ values in the SOC pool is caused by a known kinetic fractionation during respiration (Feng, 2002; Gleixner et al., 1993).

\subsection{Dissolved organic carbon}

10 Dissolved organic carbon is often discussed as a transport mechanism for organic compounds that are released during decomposition of plant material (Froberg et al., 2005; Kalbitz et al., 2003; Schwesig et al., 2003). Usually, decreasing DOC concentrations are observed with increasing depth and distance to the source such as root or litter decomposition. At our field site, DOC concentrations are primarily determined by 5 water availability. Saturation of the soil profile is only reached in late winter for short periods. Therefore, higher concentrations with increasing depth are common in fall and early winter. Interestingly, neither root exudates nor compounds set free during root turnover entered the soil solution, as indicated by carbon isotope values similar to the soil organic carbon instead of plant derived carbon, during the vegetation period 20 from spring to early fall. They were mineralized rapidly and did not contribute to the DOC composition as found by Watt et al. (2006). The major amount of organic carbon that was transported by soil solution to all depths originated from soil organic carbon present before the C3-C4 vegetation change. Only in fall and early winter did the decomposition of plant remains lead to detectable amounts of plant derived carbon in soil solution.

According to the theory that soluble organic compounds are released during litter decomposition processes, we expected higher DOC concentrations in the double litter treatment. In fact, not were only DOC concentrations lower in this treatment, but also

BGD

4, 3829-3862, 2007

Mechanisms of soil carbon storage

S. Steinbeiss et al.

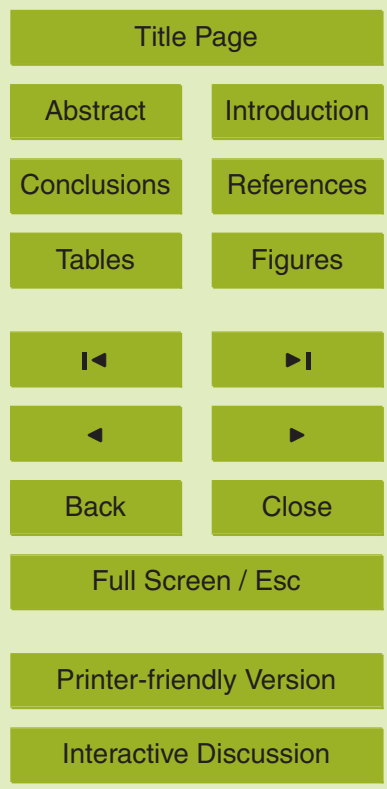

EGU 
DOC export amounts from the topmost $10 \mathrm{~cm}$ of the soil profile were the same as in the no litter treatment. Reduced evaporation and resulting higher water availability due to litter deposition probably influenced microbial activity and hence export to other horizons, as has been found in other studies (Coppens et al., 2006). After litter deposition 5 in fall, the proportion of plant derived carbon in DOC in $10 \mathrm{~cm}$ depth increased to a maximum of $29 \%$ in the double litter treatment compared to $14 \%$ in the no litter treatment. As in the soil carbon pool, the additional plant carbon source did not increase the amount of organic carbon in the soil solution but clearly increased the proportion of plant derived carbon in the DOC pool near the input source. The proposed priming of 10 microbial decomposition due to litter deposition likely led to a large reduction in the proportion of plant derived carbon in DOC between 10 and $20 \mathrm{~cm}$ depth. Together with this decrease in the proportion of plant derived carbon in DOC, a smaller export amount was also observed in this depth segment. We conclude that plant derived carbon is preferentially mineralized and adsorbed to soil particles, while mobilized soil organic 15 carbon is transported further down the soil profile. Below $20 \mathrm{~cm}$ depth, the priming still resulted in a stronger mineralization and mobilization of soil organic carbon compared to the no litter treatment. As a consequence, $15 \%$ of the soil organic carbon present in April 2002 in 20 to $30 \mathrm{~cm}$ depth was lost after two years.

The general priming of carbon turnover with double litter input found in this study, 20 ties in well with other findings at the plant level in the Jena Experiment: more diverse plant mixtures in the main experiment were up to $110 \%$ more productive (and therefore drivers of higher plant litter input) than monocultures or low diversity treatments (Roscher et al., 2005). In addition, evidence from stable isotope studies of ${ }^{15} \mathrm{~N}$ in four different plant species planted into every plot suggest a potential additional prim25 ing effect of plant diversity (species richness) on $\mathrm{N}$ turnover in these grassland plots (Temperton et al., 2007).

Decomposing roots represent the only plant carbon source for DOC in the no litter treatment. Therefore, rooting depth and root distribution controlled the input of plant derived carbon to the soil solution. Almost the same proportion of plant derived carbon

BGD

4, 3829-3862, 2007

Mechanisms of soil carbon storage

S. Steinbeiss et al.

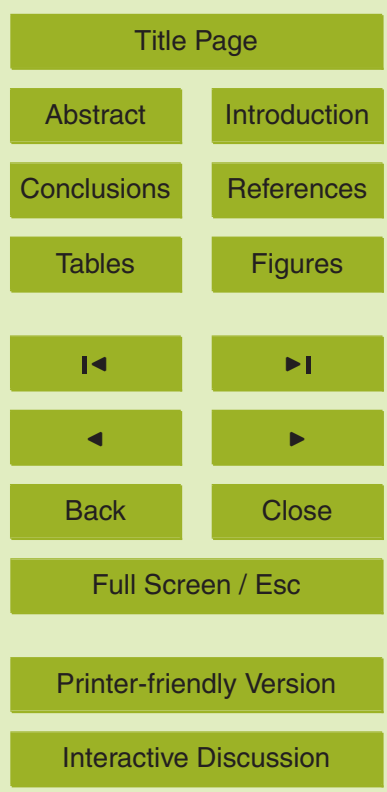

EGU 
in DOC was observed in fall in 10 and $20 \mathrm{~cm}$ depth without a time lag that would be caused by transport processes. In the absence of priming in this treatment, only $3 \%$ of soil organic carbon was lost in 20 to $30 \mathrm{~cm}$ depth. Regardless of the treatment, below $20 \mathrm{~cm}$ depth, soil solution never contained large proportions of plant derived carbon.

$5 \quad$ 4.3 Carbon storage in experimental grassland soils

In summary, our data suggest that the additional plant carbon input by litter had profound consequences on the development of the soil carbon pool (Fig. 8), at least in the short-term. With similar root biomass input to the soil that caused the increase in soil organic carbon, additional litter input accelerated carbon turnover and induced a mobi10 lization and mineralization of already present soil organic carbon. As a consequence, higher storage rates and lower carbon losses were observed without litter deposition within the first years after land use change. According to our hypothesis (1) that more carbon is transferred to the soil when additional litter is provided a higher proportion of plant derived carbon was detected in the soil organic carbon pool near the input source, but this did not result in a higher carbon accumulation.

The export amount of dissolved organic carbon by soil solution generally decreased with increasing depth. At the same scale the composition of DOC shifted from a mixture of plant and soil derived carbon to pure soil organic carbon derived compounds as hypothesized (2).

20 To complete the mechanistic model additional measurements of soil respiration or soil gas fluxes including isotope signals are necessary that allow drawing conclusions about preferential decomposition of plant or soil derived compounds and the proportions of mineralization versus transportation of the mobilized soil organic carbon. Overall, our results suggest a strong feedback link from above ground to the below ground compartments of the ecosystem, via a strong priming role of plant litter in accelerating turnover of organic carbon in the soil, not only close to the source. It is likely, that near the soil surface a part of the compounds that were set free during litter decomposition replaced already present soil organic carbon, which was then transported together with

BGD

4, 3829-3862, 2007

Mechanisms of soil carbon storage

S. Steinbeiss et al.

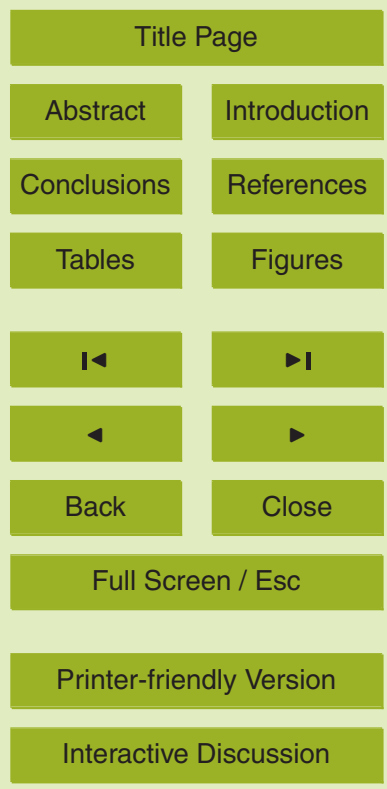

EGU 
litter derived carbon in the soil solution. With increasing distance to the input source, the proportion of plant derived carbon in the soil solution rapidly decreased, but this nevertheless still caused a priming of microbial decomposition. This in turn triggered the mobilization of SOC and lead to a relocation of inherited organic carbon to deeper 5 layers of the soil profile. Thus, the main component of DOC in soil solution at every depth investigated at any time of the year was this mobilized SOC. The transport of the DOC was controlled by water fluxes and the equilibrium between adsorption and desorption processes. A gradual readsorption of mobilized compounds to soil particles contributed (if in a minor way) to carbon storage in larger soil depths. It remains to 10 be tested whether the strong effects of plant litter on the soil carbon pool found in this short-term study, form a consistent effect in the long-term and thus may constitute a key process in carbon storage in temperate grassland soils.

Acknowledgements. This work was part of the project (GL 262-6) that was funded by the Deutsche Forschungsgemeinschaft within the scope of the Biodiversity Research Group (FOR 456) with support from the Friedrich Schiller University Jena and the Max Planck Society. We gratefully acknowledge all the people that were involved in the planning and set-up of the experiment, especially E.-D. Schulze, W. W. Weisser, B. Schmid, J. Schumacher, and C. Roscher. We acknowledge the help of Y. Oelmann and W. Wilcke in installation of the equipment and their assistance in soil solution sampling. We wish to thank all the student helpers that assisted in sampling campaigns and sample preparation, for example C. Noll, C. Seidel, M. Pieles, K. Müller, and K. Würfel. Many thanks go to the gardeners, S. Eismann, S. Junghans, B. Lenk, $\mathrm{H}$. Scheffler, U. Wehmeier, as well as the numerous student helpers who maintained the field site by weeding and regular maintenance work. We thank $\mathrm{O}$. Kolle and his team for the steady supply of data from the weather station at the field site. We thank N. Buchmann for being the 25 principle investigator of the plant ecophysiological subgroup and thus making sure that community plant stable isotope $\left({ }^{13} \mathrm{C}\right)$ measurements in the main plots of the experiment were part of the package of measurements made.

BGD

4, 3829-3862, 2007

Mechanisms of soil carbon storage

S. Steinbeiss et al.

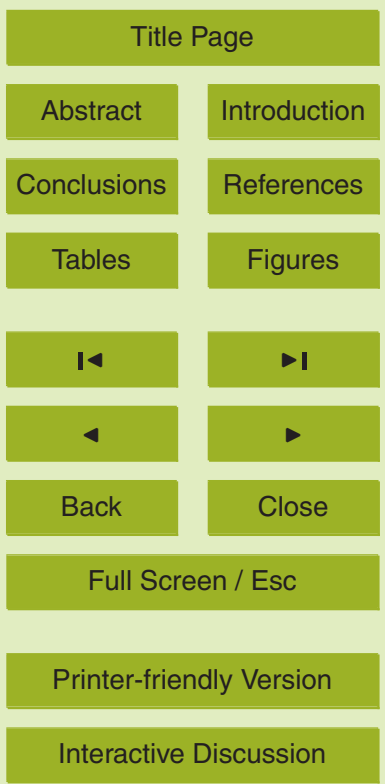

EGU 


\section{References}

Allard, V., Newton, P. C. D., Lieffering, M., Soussana, J. F., Carran, R. A., and Matthew, C.: Increased quantity and quality of coarse soil organic matter fraction at elevated $\mathrm{CO} 2$ in a grazed grassland are a consequence of enhanced root growth rate and turnover, Plant Soil, 276, 49-60, 2005.

Balesdent, J., Chenu, C., and Balabane, M.: Relationship of soil organic matter dynamics to physical protection and tillage, Soil Tillage Res., 53, 215-230, 2000.

Balesdent, J. and Mariotti, A.: Measurement of soil organic matter turnover using ${ }^{13} \mathrm{C}$ natural abundance, in: Mass Spectrometry of Soils, edited by: Boutton, T. W. and Yamasaki, S., New

10 York, 83-111, 1996.

Balvanera, P., Pfisterer, A. B., Buchmann, N., He, J. S., Nakashizuka, T., Raffaelli, D., and Schmid, B.: Quantifying the evidence for biodiversity effects on ecosystem functioning and services, Ecol. Lett., 9, 1146-1156, 2006.

Bisutti, I., Hilke, I., and Raessler, M.: Determination of total organic carbon - an overview of current methods, TrAC-Trends Anal. Chem., 23, 716-726, 2004.

Catovsky, S., Bradford, M. A., and Hector, A.: Biodiversity and ecosystem productivity: implications for carbon storage, Oikos, 97, 443-448, 2002.

Coppens, F., Garnier, P., De Gryze, S., Merckx, R., and Recous, S.: Soil moisture, carbon and nitrogen dynamics following incorporation and surface application of labelled crop residues in soil columns, Eur. J. Soil Sci., 57, 894-905, 2006.

Denef, K. and Six, J.: Contributions of incorporated residue and living roots to aggregateassociated and microbial carbon in two soils with different clay mineralogy, Eur. J. Soil Sci., 57, 774-786, 2006.

Feng, X. H.: A theoretical analysis of carbon isotope evolution of decomposing plant litters and soil organic matter, Glob. Biogeochem. Cycle, 16, GB1119, 2002.

Fontaine, S., Bardoux, G., Abbadie, L., and Mariotti, A.: Carbon input to soil may decrease soil carbon content, Ecol. Lett., 7, 314-320, 2004.

Fontaine, S. and Barot, S.: Size and functional diversity of microbe populations control plant persistence and long-term soil carbon accumulation, Ecol. Lett., 8, 1075-1087, 2005.

30 Fontaine, S., Mariotti, A., and Abbadie, L.: The priming effect of organic matter: a question of microbial competition?, Soil Biol. Biochem., 35, 837-843, 2003.

Froberg, M., Kleja, D. B., Bergkvist, B., Tipping, E., and Mulder, J.: Dissolved organic carbon
BGD

4, 3829-3862, 2007

Mechanisms of soil carbon storage

S. Steinbeiss et al.

Title Page

Abstract

Introduction

Conclusions

References

Tables

Figures

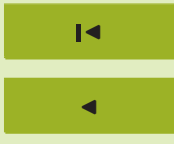

$\rightarrow 1$

Back

Close

Full Screen / Esc

Printer-friendly Version

Interactive Discussion 
leaching from a coniferous forest floor - a field manipulation experiment, Biogeochemistry, 75, 271-287, 2005.

Gill, R., Burke, I. C., Milchunas, D. G., and Lauenroth, W. K.: Relationship between root biomass and soil organic matter pools in the shortgrass steppe of eastern Colorado, Ecosystems, 2, 226-236, 1999.

Gleixner, G., Bol, R., and Balesdent, J.: Molecular insight into soil carbon turnover, Rapid Commun. Mass Spectrom., 13, 1278-1283, 1999.

Gleixner, G., Danier, H. J., Werner, R. A., and Schmidt, H. L.: Correlations between the C-13 Content of Primary and Secondary Plant-Products in Different Cell Compartments and That 10 in Decomposing Basidiomycetes, Plant Physiol., 102, 1287-1290, 1993.

Gleixner, G., Kramer, C., Hahn, V., and Sachse, D.: The effect of biodiversity on carbon storage in soils, in: Forest diversity and function: temperate and boreal systems, edited by: SchererLorenzen, M., Körner, C., and Schulze, E. D., Springer, Berlin, 165-183, 2005.

Gleixner, G., Poirier, N., Bol, R., and Balesdent, J.: Molecular dynamics of organic matter in a 15 cultivated soil, Org. Geochem., 33, 357-366, 2002.

Hooper, D. U., Bignell, D. E., Brown, V. K., Brussaard, L., Dangerfield, J. M., Wall, D. H., Wardle, D. A., Coleman, D. C., Giller, K. E., Lavelle, P., Van der Putten, W. H., De Ruiter, P. C., Rusek, J., Silver, W. L., Tiedje, J. M., and Wolters, V.: Interactions between aboveground and belowground biodiversity in terrestrial ecosystems: Patterns, mechanisms, and feedbacks, 20 Bioscience, 50, 1049-1061, 2000.

Jenkinson, D. S.: The Turnover of Organic-Carbon and Nitrogen in Soil, Philos. Trans. R. Soc. Lond. Ser. B-Biol. Sci., 329, 361-368, 1990.

Kalbitz, K., Schwesig, D., Rethemeyer, J., and Matzner, E.: Stabilization of dissolved organic matter by sorption to the mineral soil, Soil Biol. Biochem, 37, 1319-1331, 2005.

Kalbitz, K., Schwesig, D., Schmerwitz, J., Kaiser, K., Haumaier, L., Glaser, B., Ellerbrock, R., and Leinweber, P.: Changes in properties of soil-derived dissolved organic matter induced by biodegradation, Soil Biol. Biochem., 35, 1129-1142, 2003.

Kramer, C., and Gleixner, G.: Variable use of plant- and soil-derived carbon by microorganisms in agricultural soils, Soil Biol. Biochem., 38, 3267-3278, 2006.

so Kuzyakov, Y., Friedel, J. K., and Stahr, K.: Review of mechanisms and quantification of priming effects, Soil Biol. Biochem., 32, 1485-1498, 2000.

Lajtha, K., Crow, S. E., Yano, Y., Kaushal, S. S., Sulzman, E., Sollins, P., and Spears, J. D. H.: Detrital controls on soil solution $\mathrm{N}$ and dissolved organic matter in soils: a field experiment,

BGD

4, 3829-3862, 2007

Mechanisms of soil carbon storage

S. Steinbeiss et al.

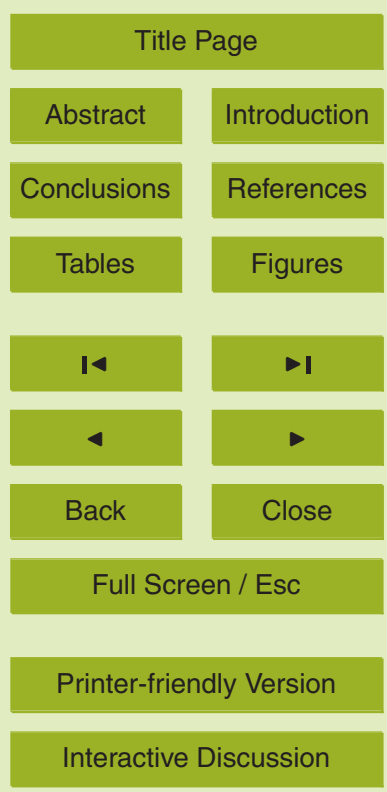


Biogeochemistry, 76, 261-281, 2005.

Lal, R.: Soil carbon sequestration impacts on global climate change and food security, Science, 304, 1623-1627, 2004a.

Lal, R.: Soil carbon sequestration to mitigate climate change, Geoderma, 123, 1-22, 2004b.

5 Lal, R., Kimble, J. M., Follett, R. F., and Stewart, B. A. (Eds.): Assessment Methods for Soil Carbon, CRC Press, 2000.

Lambers, J. H. R., Harpole, W. S., Tilman, D., Knops, J., and Reich, P. B.: Mechanisms responsible for the positive diversity-productivity relationship in Minnesota grasslands, Ecol. Lett., 7, 661-668, 2004.

10 Ostonen, I., Lohmus, K., and Pajuste, K.: Fine root biomass, production and its proportion of NPP in a fertile middle-aged Norway spruce forest: Comparison of soil core and ingrowth core methods, For. Ecol. Manage, 212, 264-277, 2005.

Parton, W. J., Stewart, J. W. B., and Cole, C. V.: Dynamics of C, N, P and S in Grassland Soils - a Model, Biogeochemistry, 5, 109-131, 1988.

Prentice, I. C.: Interactions of climate change and the terrestrial biosphere, in: Geospherebiosphere interactions and climate, edited by: Bengtsson, L. O. and Hammer, C. U., Cambridge University Press, Cambridge, 176-198, 2001.

Rasse, D. P., Rumpel, C., and Dignac, M. F.: Is soil carbon mostly root carbon? Mechanisms for a specific stabilisation, Plant Soil, 269, 341-356, 2005.

20 Rees, R. M., Bingham, I. J., Baddeley, J. A., and Watson, C. A.: The role of plants and land management in sequestering soil carbon in temperate arable and grassland ecosystems, Geoderma, 128, 130-154, 2005.

Romkens, P., van der Plicht, J., and Hassink, J.: Soil organic matter dynamics after the conversion of arable land to pasture, Biol. Fertil. Soils, 28, 277-284, 1999.

Roscher, C., Schumacher, J., Baade, J., Wilcke, W., Gleixner, G., Weisser, W. W., Schmid, B., and Schulze, E. D.: The role of biodiversity for element cycling and trophic interactions: an experimental approach in a grassland community, Basic Appl. Ecol., 5, 107-121, 2004.

Roscher, C., Temperton, V. M., Scherer-Lorenzen, M., Schmitz, M., Schumacher, J., Schmid, B., Buchmann, N., Weisser, W. W., and Schulze, E. D.: Overyielding in experimental grass30 land communities - irrespective of species pool or spatial scale, Ecol. Lett., 8, 419-429, 2005.

Schwesig, D., Kalbitz, K., and Matzner, E.: Mineralization of dissolved organic carbon in mineral soil solution of two forest soils, J. Plant Nutr. Soil Sci., 166, 585-593, 2003.

Mechanisms of soil carbon storage

S. Steinbeiss et al.

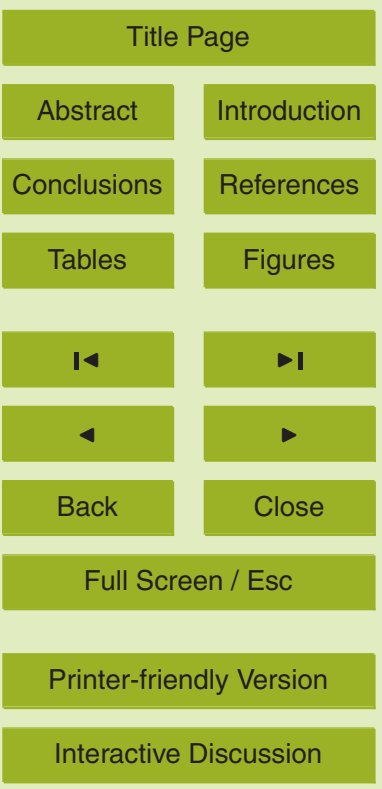


Skinner, R. H., Sanderson, M. A., Tracy, B. F., and Dell, C. J.: Above- and belowground productivity and soil carbon dynamics of pasture mixtures, Agron. J, 98, 320-326, 2006.

Stephan, A., Meyer, A. H., and Schmid, B.: Plant diversity affects culturable soil bacteria in experimental grassland communities, J. Ecol., 88, 988-998, 2000.

5 Stevens, G. N., and Jones, R. H.: Patterns in soil fertility and root herbivory interact to influence fine-root dynamics, Ecology, 87, 616-624, 2006.

Temperton, V. M., Mwangi, P. N., Scherer-Lorenzen, M., Schmid, B., and Buchmann, N.: Positive interactions between nitrogen-fixing legumes and four different neighbouring species in a biodiversity experiment, Oecologia, 151, 190-205, 2007.

10 Tilman, D., Hill, J., and Lehman, C.: Carbon-negative biofuels from low-input high-diversity grassland biomass, Science, 314, 1598-1600, 2006.

Wardle, D. A., Bonner, K. I., Barker, G. M., Yeates, G. W., Nicholson, K. S., Bardgett, R. D., Watson, R. N., and Ghani, A.: Plant removals in perennial grassland: Vegetation dynamics, decomposers, soil biodiversity, and ecosystem properties, Ecol. Monogr., 69, 535-568, 1999.

Watt, M., Silk, W. K., and Passioura, J. B.: Rates of root and organism growth, soil conditions, and temporal and spatial development of the rhizosphere, Ann. Bot., 97, 839-855, 2006.

Werner, R. A. and Brand, W. A.: Referencing strategies and techniques in stable isotope ratio analysis, Rapid Commun. Mass Spectrom., 15, 501-519, 2001.

BGD

4, 3829-3862, 2007

Mechanisms of soil carbon storage

S. Steinbeiss et al.

Title Page

Abstract

Introduction

Conclusions

References

Tables

Figures

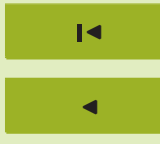

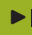

Back

Close

Full Screen / Esc

Printer-friendly Version

Interactive Discussion 
BGD

4, 3829-3862, 2007

Mechanisms of soil carbon storage

S. Steinbeiss et al.

Table 1. Correlation of soil temperature and soil moisture with DOC concentrations in soil solution (September 2003 to April 2004).

\begin{tabular}{lrr}
\hline & $\mathrm{R}$ & $\mathrm{p}$ \\
\hline soil temperature $(10 \mathrm{~cm})$ & 0.91 & $<0.001$ \\
soil moisture $(10 \mathrm{~cm})$ & -0.84 & $<0.001$ \\
soil temperature $(20 \mathrm{~cm})$ & 0.62 & 0.03 \\
soil moisture $(20 \mathrm{~cm})$ & -0.87 & $<0.001$ \\
soil temperature $(30 \mathrm{~cm})$ & 0.26 & 0.47 \\
soil moisture $(30 \mathrm{~cm})$ & -0.90 & $<0.001$ \\
\hline
\end{tabular}


BGD

4, 3829-3862, 2007

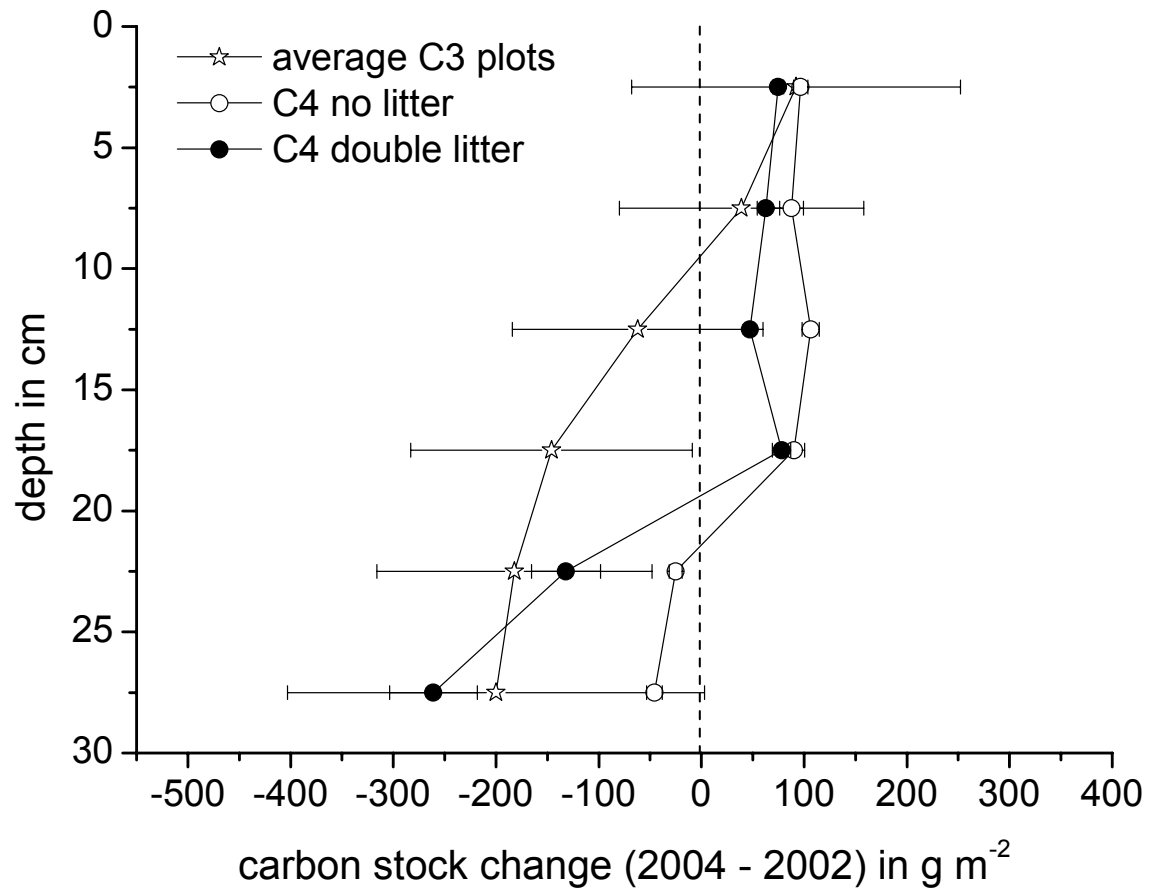

Mechanisms of soil carbon storage

S. Steinbeiss et al.

Title Page

Abstract

Introduction

Conclusions

References

Tables

Figures

14

$\rightarrow$

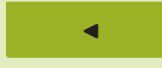

Back

Close

Full Screen / Esc

Printer-friendly Version

Interactive Discussion

Fig. 1. Stock changes of soil organic carbon to $30 \mathrm{~cm}$ depth after 2 years (2004-2002); average of all C3 plots (asterisks), C4 treatments no litter (open circles) and double litter (filled circles). Error bars represent standard deviations between $\mathrm{C} 3$ plots and within the C4 plot, respectively. 
BGD

4, 3829-3862, 2007

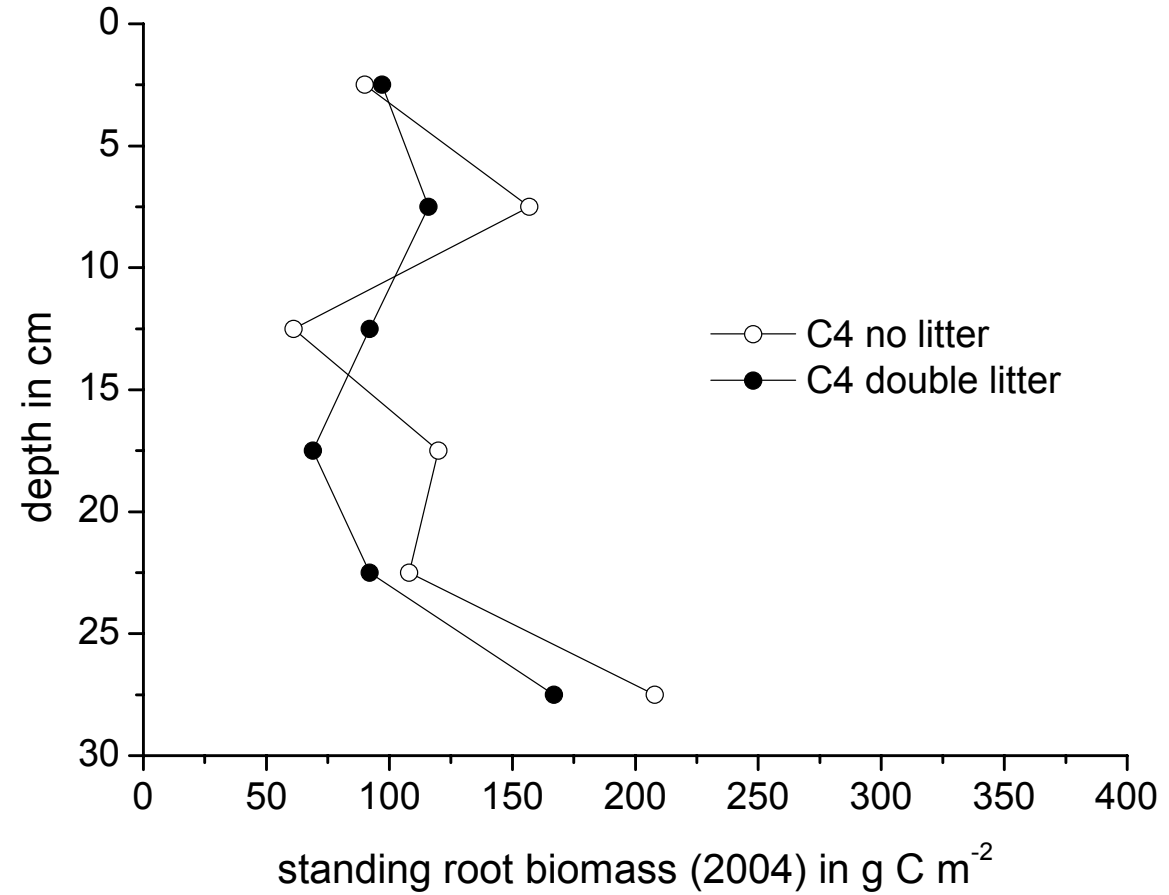

Mechanisms of soil carbon storage

S. Steinbeiss et al.

Title Page

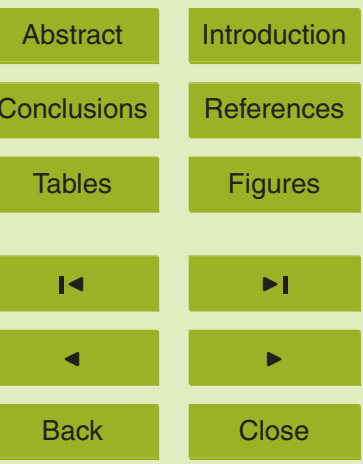

Full Screen / Esc

Printer-friendly Version

Interactive Discussion

Fig. 2. Estimates of root standing biomass $\left(\mathrm{g} \mathrm{C} \mathrm{m}^{-2}\right)$ to 30
ments no litter (open circles) and double litter (filled circles). 


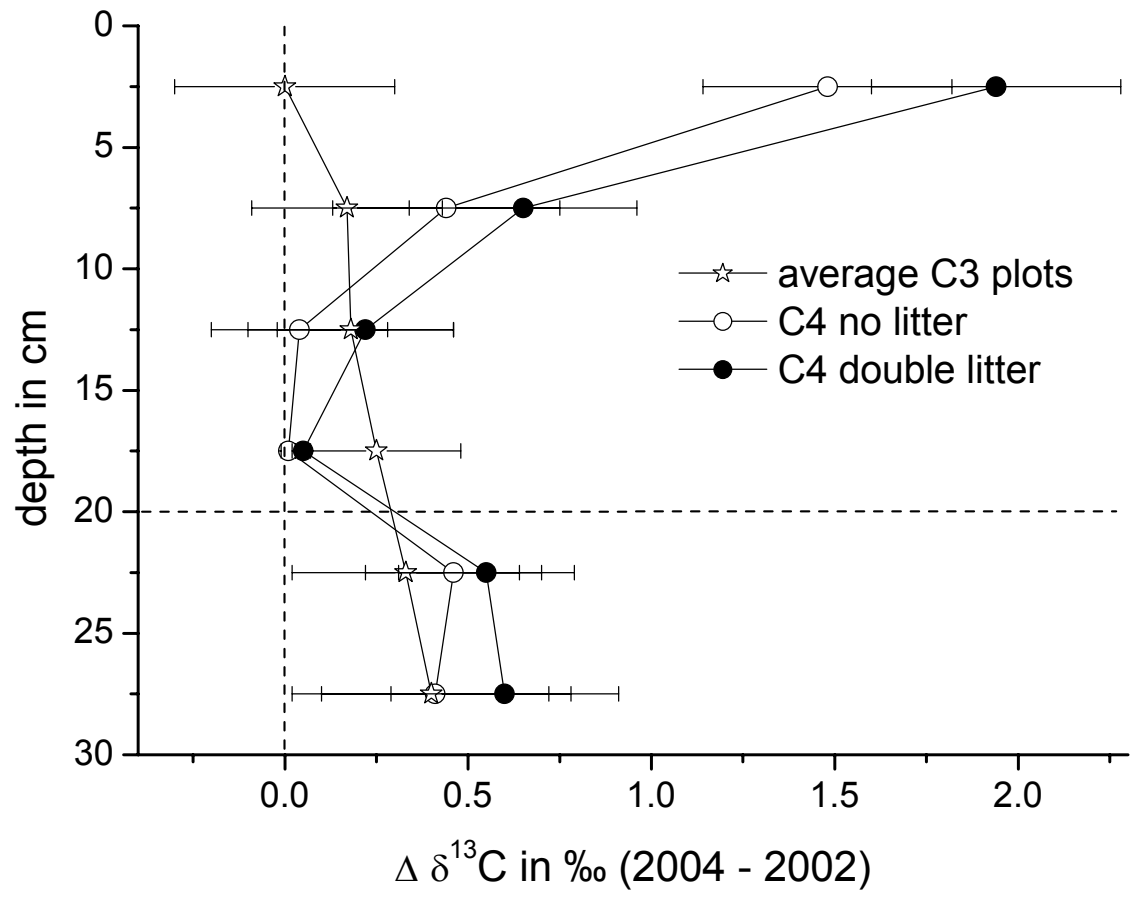

Fig. 3. Shift of carbon isotope values in soil organic carbon between 2002 and 2004 averaged for C3 plots (stars) and in C4 treatments no litter and double litter (circles); data are calculated by $\delta^{13} \mathrm{C}_{\text {soil } 2004}-\delta^{13} \mathrm{C}_{\text {soil 2002. }}$. Error bars represent standard deviations between $\mathrm{C} 3$ plots and within the $\mathrm{C} 4$ plot, respectively. The dashed lines mark zero change (vertical line) and the border for observed carbon storage in the $\mathrm{C} 4$ treatments (horizontal line).
BGD

4, 3829-3862, 2007

Mechanisms of soil carbon storage

S. Steinbeiss et al.

Title Page

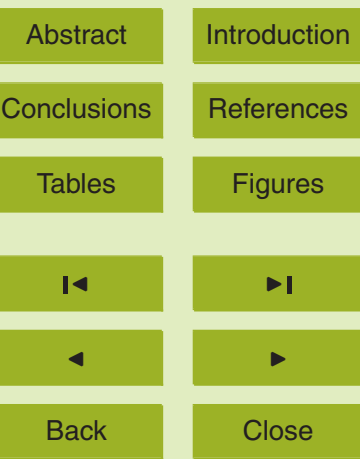

Full Screen / Esc

Printer-friendly Version

Interactive Discussion 


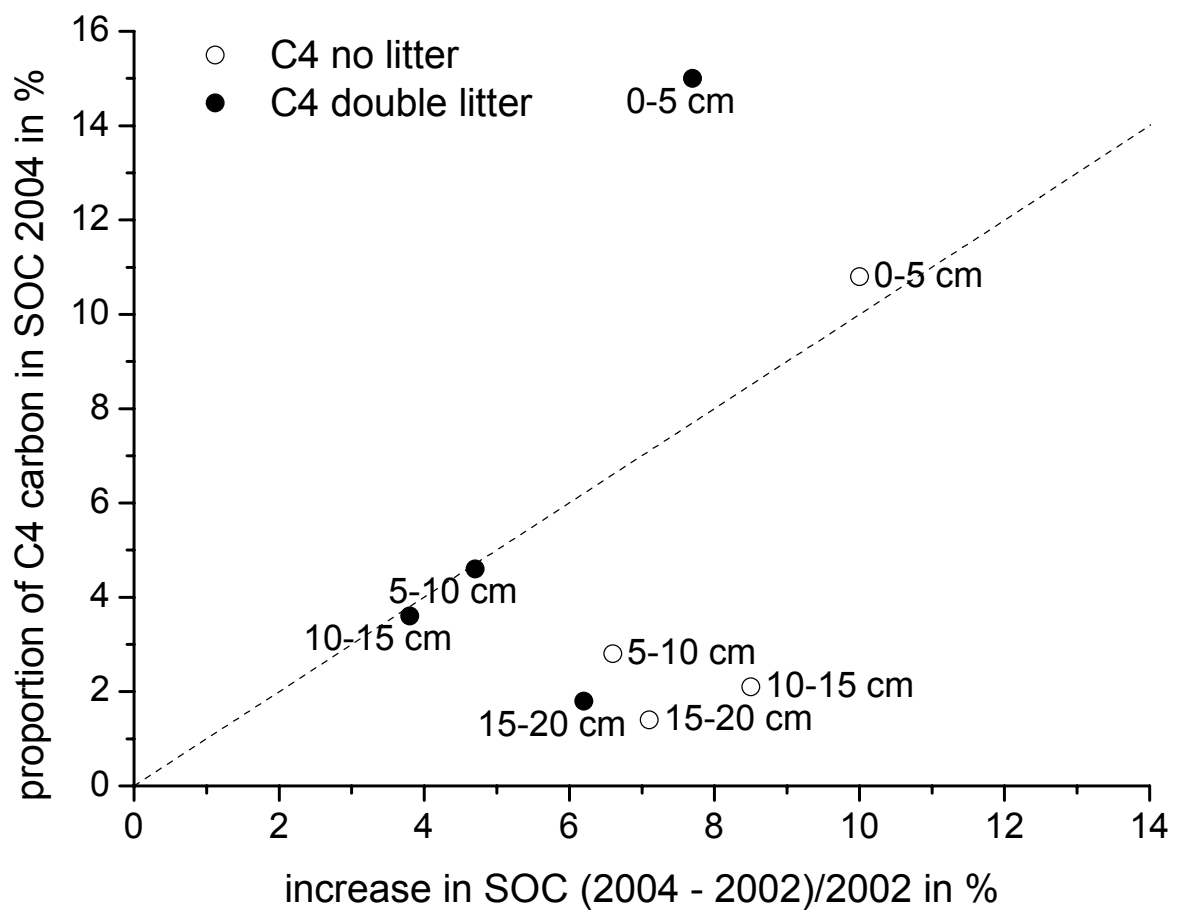

Fig. 4. Relationship between the observed increase in SOC after 2 years and the calculated proportion of incorporated C4 plant derived carbon in SOC in 2004; dashed line represents 1:1 correlation. Any data above the dashed line indicate that the proportion of $\mathrm{C} 4$ carbon derived from plants increased faster than the general increase in SOC.
BGD

4, 3829-3862, 2007

Mechanisms of soil carbon storage

S. Steinbeiss et al.

Title Page

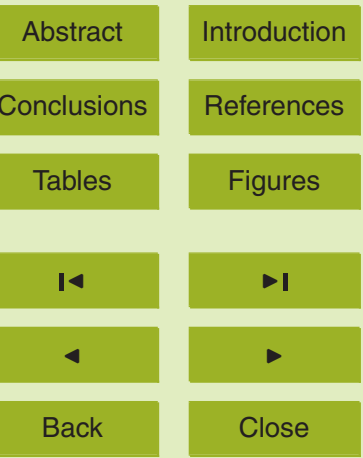

Full Screen / Esc

Printer-friendly Version

Interactive Discussion 
BGD

4, 3829-3862, 2007

Mechanisms of soil carbon storage
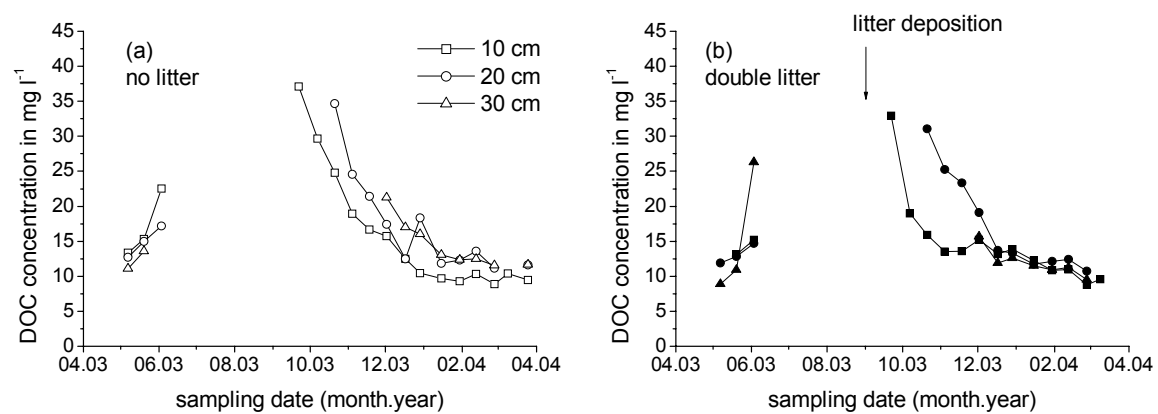

Fig. 5. Seasonal variation in DOC concentration in different depths in the no litter treatment (a) and the double litter treatment (b). The data gap is caused by summer dryness, when no free soil solution was available.

\section{S. Steinbeiss et al.}

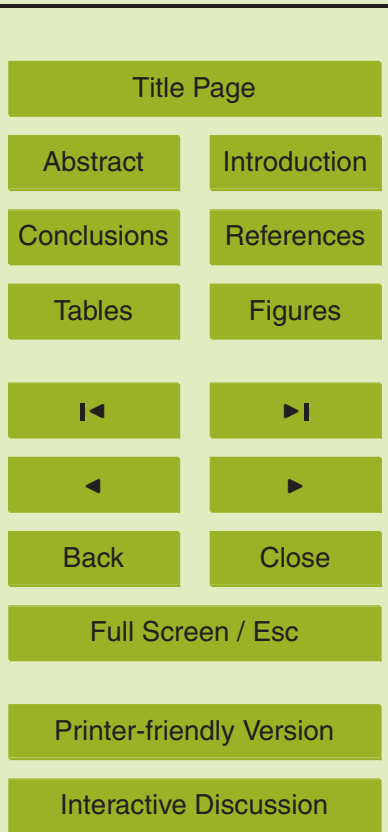


BGD

4, 3829-3862, 2007

Mechanisms of soil carbon storage

S. Steinbeiss et al.
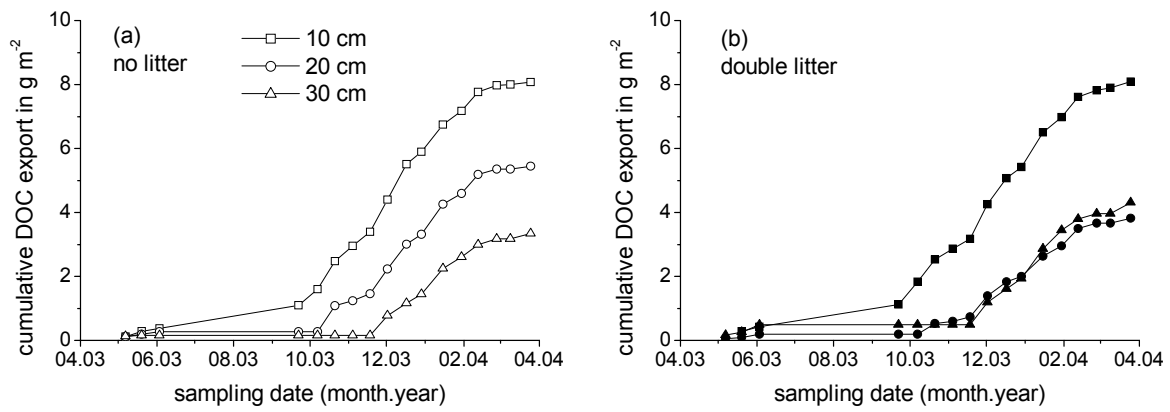

Fig. 6. Calculated cumulative carbon export from respective depths to lower depths in 2003 , in the no litter treatment (a) and the double litter treatment (b). Calculation was based on collected volumes.

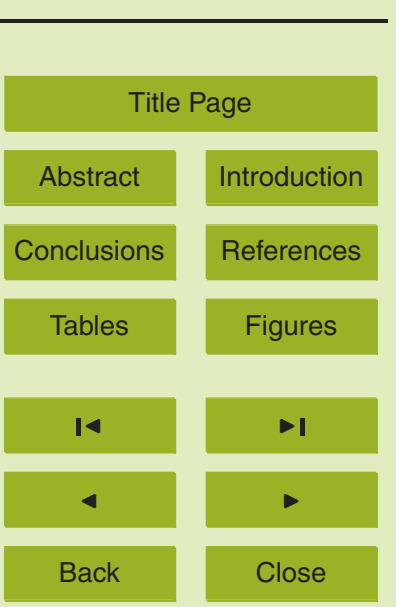

Full Screen / Esc

Printer-friendly Version

Interactive Discussion 
BGD

4, 3829-3862, 2007

Mechanisms of soil carbon storage

S. Steinbeiss et al.

$\square-10 \mathrm{~cm}$

$\longrightarrow 20 \mathrm{~cm}$

$\triangle-30 \mathrm{~cm}$

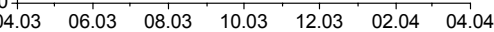
sampling date (month.year)

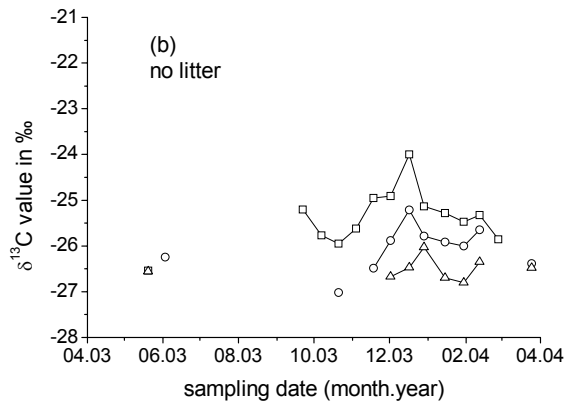

Title Page

Abstract

Introduction

Conclusions

References

Tables

Figures

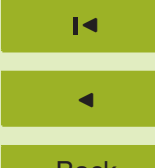

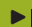

Back

Close

Full Screen / Esc

Fig. 7. Seasonal variation in $\delta^{13} \mathrm{C}$ values of $\mathrm{DOC}$ in different depths averaged for plots with $\mathrm{C} 3$ vegetation (a), in the C4 no litter treatment (b) and in the C4 double litter treatment (c). 
BGD

4, 3829-3862, 2007

Mechanisms of soil carbon storage

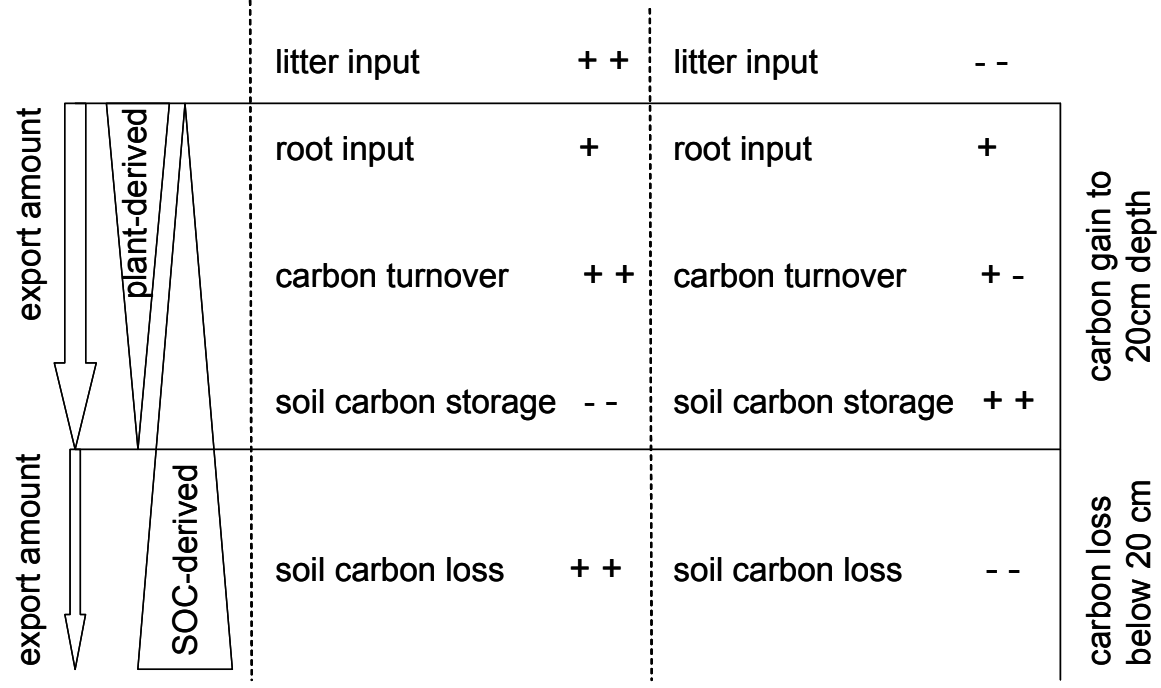

Fig. 8. Mechanistic model of consequences of additional litter input and similar root input on the development of the soil carbon pool. The thickness of the arrows denotes amounts, plus indicates addition or amplification, and minus indicates removal or attenuation.
S. Steinbeiss et al.

Title Page

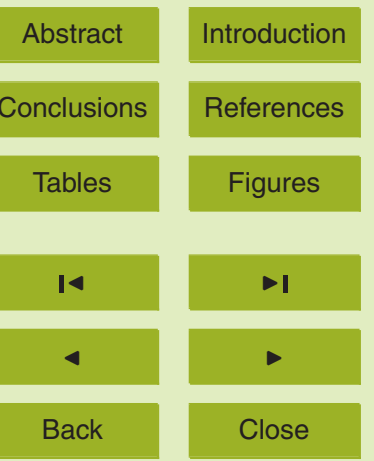

Full Screen / Esc

Printer-friendly Version

Interactive Discussion 